NBER WORKING PAPER SERIES

\title{
THE RECONSTRUCTION OF THE AMERICAN URBAN LANDSCAPE IN THE TWENTIETH CENTURY
}

\author{
Sukkoo Kim \\ Working Paper 8857 \\ http://www.nber.org/papers/w8857 \\ NATIONAL BUREAU OF ECONOMIC RESEARCH \\ 1050 Massachusetts Avenue \\ Cambridge, MA 02138 \\ April 2002
}

I would like to thank Will Strange for his kind and thoughtful suggestions. Comments from Marcus Berliant, Rebecca Menes, Chuck Moul, Fred Smith, Brian Spicher, and the seminar participants at the Economic History Association meetings in Los Angeles, California, Regional Science Association meetings in Charleston, South Carolina, ASSA Meetings in Atlanta, Georgia, and workshops at University of British Columbia, Kansas City Federal Reserve, UCLA and Washington University, are also gratefully acknowledged. The views expressed herein are those of the author and not necessarily those of the National Bureau of Economic Research.

(C) 2002 by Sukkoo Kim. All rights reserved. Short sections of text, not to exceed two paragraphs, may be quoted without explicit permission provided that full credit, including (C) notice, is given to the source. 
The Reconstruction of the American Urban Landscape in the Twentieth Century

Sukkoo Kim

NBER Working Paper No. 8857

April 2002

JEL No. R11, N70

\begin{abstract}
One of the most important representations of an urban spatial structure is its density. Indeed, an urban area is defined as a densely populated place with a sizeable number of inhabitants. Yet, despite the fact that the defining element of an urban area is its density, few scholars have systematically examined the long-run changes in the densities of economic activities in these areas. This paper documents the historical changes in population and employment densities in U.S. cities and metropolitan areas and explores the causes of their rise and decline between the late nineteenth and the twentieth centuries.
\end{abstract}

\title{
Sukkoo Kim
}

Department of Economics

Washington University in St. Louis

St. Louis, MO 63130

and NBER

soks@wueconc.wustl.edu 


\section{Introduction}

The spatial organization of American cities has changed dramatically over the last two centuries. While the signs of previous eras are still visible in the streets and architecture of historic buildings in many cities, one of America's most distinctive characteristics has been its willingness to constantly reconstruct and modify its spatial environment. The exchanges and warehouses near the waterfront, the hallmarks of nineteenth century port cities, are gone. The cast-iron, masonry office buildings were torn down and replaced with modern steel skeletalframed skyscrapers. The streets which move people and goods throughout the city have been redesigned with each advance in transportation. The row houses and tenements have given way to apartments and single-detached houses.

This paper examines the changes in the spatial structures of urban areas in the United States between the late nineteenth and the twentieth centuries. The spatial structure of an urban area is measured using average densities of population and employment. ${ }^{1}$ While there is no single measure that will fully capture the spatial structure of an urban area, the average density is one of the most useful and widely used. Indeed, a city or an urban area is typically defined as a densely populated place with a sizeable number of inhabitants. Yet, despite the fact that the defining

${ }^{1}$ Density is measured as gross average density or simply as employment or population divided by the urban area. Net density, or the activity divided by area devoted to that specific activity, is preferred but is practically impossible to calculate. In principle, the average density and net density will be correlated if the area of land devoted to different kinds of activities, industry, commercial, and residential, remain relatively stable across cities and over time. Bartholomew (1955) finds that land uses for 55 cities were allocated to the following uses: residential (39.61\%), commercial (3.32\%), industrial (6.44\%), railroad $(4.86 \%)$, streets $(28.19 \%)$, and public property (17.67\%). It is also possible to derive a weighted average measure using a finer level of aggregation such as the census tract. However, this measure is prohibitive in that it is costly to construct for the samples of cities in this paper and it is very likely that these two measures are highly correlated (see Glaeser (1998)). 
element of an urban area is its density, few scholars have systematically examined the long-run changes in the average densities of urban areas.

Most scholars believe that dense urban areas arise as firms agglomerate near each other in order to take advantage of some kind of increasing returns. ${ }^{2}$ In recent years, the focus has been on a variety of external economies of scale such as Marshallian externalities and other economies resulting from large markets. ${ }^{3}$ However, other sources such as scale economies in the production of goods and services, in the provision of local public goods, and in transportation may contribute to the formation of urban areas. ${ }^{4}$ Surprisingly, most empirical work which attempts to identify the sources of increasing returns responsible for the rise of dense urban areas examines population, employment, or output levels rather than their densities. These studies often examine why cities are specialized or diversified and whether population growth in urban areas are correlated with specialized or diversified cities. ${ }^{5}$

The study of spatial organization within a given city is dominated by the classic urban model called the monocentric city model. ${ }^{6}$ The monocentric city model assumes that firms are

${ }^{2}$ See Mills (1967).

3 See Fujita and Thisse (2001), Duranton and Puga (2000), and Hanson (2001) for a review of the recent literature. Also see Kim $(1995,1998,1999)$.

${ }^{4}$ See Berliant and Wang (1993), Berliant and Konishi (2000), and Konishi (2000) for models of city formation using market places (or local public goods) and transportation. The work of Helsley and Strange (1990) also has external economies that have a local public goods nature.

5 For examples, see Glaeser et. al (1992) and Henderson (1988), Black and Henderson (1998), Henderson, Kuncoro and Turner (1995), Kim (2000), Rosenthal and Strange (2001), and Dobkins and Ioannides (2001). For exceptions, see Ciccone and Hall (1996), Chatterjee and Carlino (1998) and Carlino and Chatterjee (1999).

6 The monocentric model was developed by Alonso (1964), Muth (1969), Mills (1972), Wheaton (1977) and others. Also see Fujita (1989). 
exogenously located in the central business district (CBD). Households choose residential locations and consumption of housing and other goods and services. All households commute to the CBD for work. Since it is costly to commute, the households who live further away from the CBD are compensated by a lower price of land and greater consumption of housing. The model predicts that a household's consumption of housing increases or population density declines at greater distances from the CBD.

The majority of empirical work based on the monocentric city model uses a measure called the density gradient to capture the spatial organization of a given urban area. ${ }^{7}$ The density gradient measures the changes in the density of an urban area as one moves further away from the CBD. Many urban scholars define the process of suburbanization as the decline in the density gradient. Most studies indicate that, as predicted by the monocentric city model, density declines monotonically from the city center. In addition, in the United States, the density gradient of cities has consistently fallen or flattened over time. Since the monocentric city model predicts a flattening of the density gradient when incomes rise or when transportation costs fall, the most popular explanation for suburbanization has been rising incomes and falling commuting costs

This paper differs from the existing empirical literature on cities in two important ways. First, as indicated above, this paper examines the average density of cities rather than population or employment levels or density gradients. The data on the long-run trends in the average density of cities and metropolitan areas present a strikingly different picture of changes in the U.S. urban

${ }^{7}$ The density gradient is estimated using a negative exponential function: $D(x)=D_{0} e^{-\gamma x}$ where $\mathrm{D}(\mathrm{x})$ is the population density at distance $\mathrm{x}$ from the center, $\mathrm{D}_{0}$ is the density at the center, and $\gamma$, the density gradient, is the proportional rate at which population density falls with distance from the CBD. 
spatial structure than the more popular density gradients. ${ }^{8}$ Second, despite the lack of a formal model, this paper adopts an empirical approach which takes both firm and household location as endogenous. In particular, this paper uses the simultaneous equations approach developed by Steinnes and Fisher (1974) to explain the population and employment densities of urban areas. ${ }^{9}$ However, unlike most studies of this type, this paper will combine the elements of the models of city formation and the monocentric city model. This paper assumes that the models of city formation explain employment density given population density whereas the monocentric city model explains population density given employment density.

The data on the average density of urban areas between the late nineteenth and the early twentieth centuries provide a different but complementary picture of the changes in the spatial organization of U.S. urban areas than that based on density gradients. The studies of density gradients of U.S. cities indicate that it has declined monotonically over time. ${ }^{10}$ However, data on average population and employment densities for consistent samples of cities and metropolitan areas show that the densities of urban areas rose modestly between the late nineteenth and the early twentieth centuries but then fell rapidly over the second half of the twentieth century. The

${ }^{8}$ For example, in 1940, the density gradients of New York, Chicago, Boston and Los Angeles were $0.21,0.21,0.31$ and 0.27 respectively (see Anas, Arnott and Small (1998)). These density gradients suggest that New York and Chicago were more suburbanized than Boston and Los Angeles. However, the average densities of these cities provide a very different picture of urban spatial structure. In 1940 the figures for New York, Chicago, Boston and Los Angeles were 24,933, 16,434, 16,721, and 3,356 persons per square mile, respectively. As expected, the average density of New York is much higher than other cities.

9 The simultaneous equation model was developed to determine whether "people follow jobs" or "jobs follow people." See Steinnes and Fisher (1974), Grubb (1982), Carlino and Mills (1987), and Thurston and Yezer (1994).

10 See Clark (1951), Mills (1972), Muth (1969), and Edmonston (1975). 
data also exhibit significant regional variation in the density of cities. The cities in the Middle Atlantic region were significantly more dense than cities in other regions for most of the period.

This paper finds that the trends in employment and population densities of urban areas are explained by the joint location decisions of firms and households. First, the analysis of employment density of cities and metropolitan areas suggests that there are significant urban scale economies resulting from the spatial concentration of middlemen who coordinate trade. The data indicate that density is correlated with specialization in transaction services such as wholesale trade, finance, insurance and real estate. Second, the analysis of population density indicate that the monocentric city model provides a useful framework studying density in urban areas. The data suggest that falling transportation costs and rising incomes are both likely to have contributed to a reduction in the population density of urban areas. Finally, the data analysis indicate that firms' and households' location decisions influenced each other. Thus, the rapid decline in population and employment densities of urban areas in the second half of the twentieth century is likely to have been caused by the fact that these forces were re-enforcing each other.

The paper is organized as follows. Section II documents the changes in the density of cities and metropolitan areas between the late nineteenth and the twentieth centuries. Section III examines the determinants of urban spatial structures. The monocentric city model and the general equilibrium model of population and employment densities are estimated for samples of cities and metropolitan areas. Section IV concludes with a summary.

II. The Density of Urban Areas

This section presents data on the density of cities and metropolitan areas between the late nineteenth and the twentieth centuries. The data on the density of cities are constructed using 
samples of cities whose populations are greater than 25,000 inhabitants for each decade between

1890 and 1990. The data are from the Social Statistics of Cities, 1890, Financial Statistics of

Cities 1901-1940, and County and City Data Book, 1949-1994. The data on the density of

metropolitan areas for 1910 to 1940 are from Thompson (1948) and are based on the

"metropolitan district" concept. ${ }^{11}$ The data for the decades between 1940 to 1990 are based on the

"metropolitan area" concept and come from a variety of sources such as the County and City

Data Book, 1949-1977, State and Metropolitan Area Data Book, 1980-1990, Census of

Population, 1990, and Census of Housing and Population, $1990 .^{12}$

The data on the average density of cities and metropolitan areas provide an important

view of the changes in the American urban landscape between the late nineteenth and the

twentieth centuries. Unlike the picture provided by the estimates of density gradients, which

11 The Census Bureau's first attempt to define a metropolitan area was in 1910. In that year, the census officials defined two types of "metropolitan districts" that differed in terms of threshold levels for population and density. For cities with populations of at least 200,000, the "metropolitan district" was defined as the political city boundary plus any contiguous minor civil divisions and incorporated places having a population density of at least 150 persons per square mile. For cities with populations of 100,000 to 200,000 , the "metropolitan district" was defined as the municipal city plus all cities, towns, villages or other divisions located within 10 miles of the central city. However, in 1930, the threshold population level was lowered to 50,000 and the threshold density criterion of 150 persons per square mile was applied to all "metropolitan districts."

12 Despite the fact that the "metropolitan district" accorded well with the economists' conception of an urban area, the metropolitan area was completely redefined by the Bureau of the Budget (Office of Management and Budget) in 1949. Since the Census Bureau's "metropolitan district" did not coincide with county boundaries, the amount of useful information that could be reported for these areas was severely limited. Thus, the new "metropolitan area" was defined using county boundaries rather than the population density criteria. For cities with 50,000 or more inhabitants, except in New England, the metropolitan area was defined as the city and its county and one or more contiguous counties that were socially and economically integrated to the central county. In New England, cities and towns, rather than counties were used to define metropolitan areas. Although the "metropolitan area" concept has been modified on numerous occasions, the use of county boundaries has remained constant since its inception in 1949. The standards for establishing whether or not a county should be included as a metropolitan area depends on a variety of considerations such as density, commuting patterns, and industrial structure, among others. For a 
decline monotonically over time, the data on average density of urban areas suggest that the pattern of urban spatial organization has changed dramatically over time. Except for the full sample of cities, whose overall average density is clouded by the entry of new cities into the sample, the data indicate that population and employment densities in urban areas increased during the period between the late nineteenth and the mid-twentieth centuries. However, during the second half of the twentieth century, urban density declined significantly.

\section{Density of Cities}

In Table 1 and Figure 1, data on the average density of cities are presented for samples of cities whose population is greater than 25,000 for every decade between 1890 and 1990 . Over time, as the population grew and became more urban, the number of cities in the sample increased from 122 in 1890 to 1068 in $1990 .{ }^{13}$ The data indicate that the density of cities declined slightly over the first half of the twentieth century but fell sharply over the second half. In 1890, the average density of cities was 7,648 persons per mile and in 1930, despite a three-fold growth in the number of cities in the sample, average density remained around 7,366. However, between 1930 and 1990, as the cities in the sample grew another three-fold, the figure fell almost by half to 3,789 persons per mile. ${ }^{14}$ Since density is defined as population divided by land area, changes in density are caused by changes in population or land area. The data on average population and land area reported in Table 1 suggest that changes in both population and land area contributed

more detailed discussion, see the State and Metropolitan Area Data Book, 1991.

13 The long-run trends in U.S. urban development is more fully addressed in Kim (2000).

14 In 1890, the New York city region had three cities, Brooklyn, Long Island, and New York in the sample; in 1898, these and other cities were consolidated to form the current greater New York city. If the 1890 density was calculated using the 1898 definition of New York, the average density was 7253 . 
significantly to the decline of population density in the second half of the twentieth century.

The study of city density by region shows that the long-run trend in average density was replicated by most cities in all regions (see Figure 2 and Table 2). However, there were some significant regional variations. First, the cities in the Middle Atlantic region were significantly more dense than those in other regions over most of the period. In 1920, the average density of cities in the Middle Atlantic was 12,208 persons per square mile whereas the figure ranged from 4,210 to 7,809 for cities in other regions. In 1990, the average density of the Middle Atlantic cities was 8,212 persons per square mile and was often two to three times more dense than cities in other regions. Second, the cities in the two southern regions, South Atlantic and West South Central, were as dense as those in the Middle Atlantic in the late nineteenth century, but their densities declined rapidly over the twentieth century. Finally, the cities in the two Western regions, despite their reputation for low density, were just as dense as those in most other regions Since the samples of cities in Table 1 change over time, it is difficult to know whether the overall changes in the average density of cities are caused by changes in the composition of cities or by secular changes in each city. Therefore, a consistent sample of cities was constructed by taking the intersection of cities in each decade between 1890 and 1990. Figure 3 and Table 3 provide data on the density of cities for a consistent set of 119 cities. In contrast to the full sample of cities, the average density of this consistent sample increased by 21 percent between the late nineteenth and the mid-twentieth centuries. ${ }^{15}$ In 1890 , the average population density was

15 While scholars have written about the developments in transportation which contributed to the outward radiation of population and employment, there has been less written about the innovations in building technology that contributed to the growth of population and employment densities during this period (see Warner (1962)). For example, advances in fire proofing columns and elevator technology allowed building heights to increase from 4 to 10 stories during the late $1880 \mathrm{~s}$. Other advances in metal 
7203 persons per mile and the figure rose to 8697 and 8876 in 1920 and 1950 respectively. The difference in the trends between the full and the consistent samples are likely caused by the fact that the new cities that came into the full sample were generally less densely populated than the existing cities at any given point in time. However, between the middle and the latter half of the twentieth century, the average density of cities in the consistent sample, like that of the full sample, fell by 45 percent. In 1990, the average population density of cities in the consistent sample was 5647 persons per mile.

The data in Table 3 indicate that the changes in the density of cities were influenced by changes in urban population and urban land area (annexation). Between 1890 and 1910, urban population growth placed significant upward pressures on density, but these pressures were kept in check by the annexation of significant new areas. During these two decades, population in these 119 cities grew on average by $25 \%$ and $30 \%$ in each decade; however, annexations increased the land area of these cities by $20 \%$ and $28 \%$ in each decade. During the interwar years, the changes in the density of cities, population, and land areas of these cities were relatively small. However, during the second half of the twentieth century, annexation, and to a lesser extent, a decline in urban population growth both contributed to significant declines in the densities of these cities. In the postwar years, annexation was most significant between 1950 and 1970, but did not reach the rates of growth experienced between 1890 and 1910. On the other hand, city population declined most significantly between 1970 and 198

The data on density for the consistent sample of cities exhibit significant variations by

framing, wind bracing, secure anchoring, power construction equipment, heating, ventilation, plumbing and lighting all contributed to the rise in building heights of skyscrapers between the late nineteenth and the early twentieth centuries. See Landau and Condit (1996). 
age. Figure 4 presents data on average density of cities categorized by their dates of incorporation: $1653-1800,1801-1830,1831-1840,1841-1850,1851-1860$, and 1861-1889. In each age cohort, the average density rose between late nineteenth and the mid-twentieth century, and then fell over the second half of the twentieth century. However, at any given point in time, the average population densities of older cities were consistently higher than those of younger cities. On average, the cities that were incorporated before 1830 were more dense than those that were incorporated between 1831 and 1860, and the latter cities, in turn, were more dense than those incorporated between 1861 and $1889 .^{16}$

Finally, figures 5 and 6 present average population densities of cities weighted by population size. The population weighted data for both the full and the consistent samples exhibited inverted-U patterns over time. Figure 5 shows that the weighted average density of cities for the full sample, unlike the unweighted average, rose between 1890 and 1930, fell slightly between 1930 and 1950, and then, like the unweighted average, fell significantly over the second half of the twentieth century. ${ }^{17}$ Figure 6 , which presents weighted average density data for the 119 consistent sample of cities, shows that the weighted average rose more steeply than the unweighted between the late nineteenth and the mid-twentieth centuries, and then fell less steeply than the unweighted consistent sample in the second half of the twentieth century. Thus, the weighted average density data indicate that larger cities tended to be more dense than smaller

16 The incorporation date is statistically significant in every decade when it is regressed on average density and remains significant even when regional dummies are included.

17 The 1898 definition of New York city was used to define density for 1890 . If the 1890 definition is used, then the weighted average is significantly higher at 12,715 persons per square mile. The 1890 definition for New York includes Brooklyn and New York; the consolidated 1898 definition includes Manhattan, Bronx, Brooklyn, Queens, and Richmond boroughs. 
cities in both the full and the consistent sample.

\section{Density of Metropolitan Area}

The study of the changes in the density of "metropolitan districts" between 1910 and 1940 are particularly challenging since the definition of the "metropolitan district" was rarely consistent across metropolitan areas and over time. Thompson's (1948) data on metropolitan districts use the 1940 metropolitan district area definition for all previous years. ${ }^{18}$ The Thompson's data on metropolitan districts indicate that their average densities fell between 1910 and 1940. Table 4 shows that in 1910, the 30 metropolitan districts averaged 1910 persons per square mile; in 1940, the 92 metropolitan districts averaged 1140. Table 4 also shows data on density for 30 identical metropolitan districts over time. The data indicate that density rose slightly between 1910 and 1920 from 1910 to 2042 persons per mile but then fell to 1678 in 1940. However, a closer examination of changes in the average land area of metropolitan districts between 1920 and 1930 suggests that the significant decline in density is likely to have been caused by a change in the definition of the metropolitan district. ${ }^{19}$

Data based on "metropolitan area" concept appear to be much more consistent over time than those available by "metropolitan districts" despite the periodic changes in its definition. ${ }^{20}$

18 Bogue (1953) also provides data on metropolitan areas for the period between 1900 and 1950. Bogue uses the 1950 census definition and reconstructs what the metropolitan populations would have been if the 1950 definition was applied for earlier periods. Since some portions of the 1950 metropolitan area were likely to have been rural in 1900, urban density calculated from Bogue's data are likely to result in a downward bias for the earlier period.

19 Between 1930 and 1940, the average land area of the 30 metropolitan area districts jumps by 202 square miles from 348 to 550 . On the other hand, in the other years, the average decadal change is less than 30 square miles.

20 The "metropolitan area" has been redefined at the time of each census since 1949. Thus, it is 
Table 5 and Figure 7 present data on metropolitan areas using the definition given at any point in time. The data on metropolitan areas indicate that their density rose between 1940 and 1960, but then declined significantly between 1960 and 1990. Between 1940 and 1960, the density of metropolitan areas rose from 387 to 589 persons per square mile. However, by 1990, density declined substantially to $288 .^{21}$

Table 6 presents data for a consistent sample of 149 metropolitan areas. Unlike cities, the data show that the trend for the consistent sample was almost identical to that of the full sample. The density of metropolitan areas for the consistent sample rose between 1940 and 1960 but then fell dramatically over the second half of the twentieth century (see Figure 8). In 1940, metropolitan areas averaged 389 persons per square mile; in 1960, the figure rose to 547 but in 1980, it fell to 442. The examination of the changes in population and land areas suggests that the increase in the density of metropolitan areas between 1940 and 1960 was caused entirely by an increase in metropolitan population. Table 6 shows that the metropolitan population grew by more than 23\% in each decade between 1940 and 1960; however, the metropolitan land area changed negligibly between 1940 and 1950 and rose by about $10 \%$ between 1950 and 1960 . On the other hand, the data indicate that the decline in the density of metropolitan areas was caused

difficult to know how much of the changes in the density over time can be attributed to changes in the definitions. However, the redefinition of the "metropolitan area" has resulted in only modest changes over time. Between 1940 and 1980, the metropolitan area data were categorized at the smallest metropolitan unit designated as the standard metropolitan area (SMA) or standard statistical metropolitan area (SMSA). However, in 1983, the metropolitan data were re-categorized into three different levels: metropolitan area (MSA), primary metropolitan area (PMSA), and consolidated metropolitan area (CMSA).

21 The 1990 data in Table 6 use CMSA's. Since average density declines as the definition of metropolitan area becomes more consolidated, a portion of this decline can be attributed to the change in the definition of metropolitan areas. 
entirely by the growth in the average size of metropolitan areas. Between 1960 and 1980, land area grew by an average of $27 \%$ in each decade. Over this period, the metropolitan population continued to grow at $18 \%$ per decade, but its growth was not enough to offset the significant growth in land area.

\section{Determinants of Urban Spatial Structure}

This section explores some of the causes of urban spatial structures using models of city formation and the monocentric city model in a simultaneous equation framework where firm and household locations are both assumed to be endogenous. ${ }^{22}$ First, motivated by the monocentric city model, the population density of an urban area is assumed to depend upon household demand for housing, which in turn depends upon household income and local transportation $\operatorname{costs}^{23}$ Second, motivated by the models of city formation, this paper assumes that employment density depends upon the firm location decisions which in turn depend upon the nature and strength of agglomeration economies as well as the intensities of land use of firms in various industries. Third, this paper assumes that population and employment densities influence each other. In addition, this paper examines why city age is correlated with urban density.

22 See Steinnes and Fisher (1974), Grubb (1982), Mills and Price (1984), Carlino and Mills (1987), Greenwood and Stock (1990), Thurston and Yezer (1994), and Deitz (1998). Most of these studies use population and employment density gradients rather than their average densities.

23 There are many versions of the monocentric city model. This paper adopts Fujita's (1989) version of the closed city model under absentee landownership where the urban fringe is determined by an exogenous agricultural land rent. In general, scholars seem to be interested in understanding the density gradients rather than average densities of cities. Thus, most of the comparative statics results are derived for density gradients. However, the monocentric model also determines the density of urban areas. In this model, if urban population increases, then housing lot size decreases everywhere and average population density increases. However, given a level of urban population, a rise in income or a decline in transportation costs increases the urban boundary and thereby lowers average population density. See Fujita (1989), chapter 3, for results on comparative statics. 
The regression estimates consist of two separate sets of equations. One estimate is based on the monocentric city model which suggests that housing demand is a function of income and transportation costs:

$$
H_{i}=\alpha_{1}+\alpha_{2} Y_{i}+\alpha_{3} T_{i}+\varepsilon_{H}
$$

where $\mathrm{H}_{\mathrm{i}}$ is housing, $\mathrm{Y}_{\mathrm{i}}$ is income, and $\mathrm{T}_{\mathrm{i}}$ is the cost of local transportation. The second set of estimates are based on the simultaneous equations of population and employment densities. Population density is assumed to be a function of employment density, housing and climate:

$$
\mathrm{P}_{\mathrm{i}}=\beta_{1}+\beta_{2} \mathrm{E}_{\mathrm{i}}+\beta_{3} \mathrm{H}_{\mathrm{i}}+\beta_{4} \mathrm{C}_{\mathrm{i}}+\varepsilon_{\mathrm{P}}
$$

where $\mathrm{P}_{\mathrm{i}}$ and $\mathrm{E}_{\mathrm{i}}$ are population and employment densities, respectively, and $\mathrm{H}_{\mathrm{i}}$ is housing and $\mathrm{C}_{\mathrm{i}}$ is climate; and, employment density is assumed to be a function of population density and a vector of explanatory variables that capture industry agglomeration economies:

$$
E_{i}=\gamma_{1}+\gamma_{2} P_{i}+\gamma_{3} X_{i}+\varepsilon_{E}
$$

where $\mathrm{X}_{\mathrm{i}}$ is a vector of explanatory variables. Equation (1) is estimated using ordinary least squares and equations (2) and (3) are estimated using 2 sls or instrumental variables estimations.

Due to a variety of data limitations, this paper estimates these equations using crosssectional data on cities with population levels of more than 25,000 and for all metropolitan areas in 1950 and 1990. Panel data of any length are difficult to construct due to frequent data reporting changes. It is also difficult to estimate equations (1) and (2) for earlier periods due to the lack of data on housing. However, it is possible to estimate equation (3) for earlier periods.

The monocentric city model is estimated using various proxy measures for housing lot size, incomes and local transportation costs. Since data on housing lot sizes are unavailable, the dependent variable chosen for this study was the percentage of single-detached or owner- 
occupied housing. The data on incomes vary from median income, income per capita and household incomes. The available data on transportation costs also vary; they range from the shares of commuters using public transportation or automobiles, trucks and vans to per capita automobile registration rates. The independent variables in the population density equation, in addition to the housing variable, include two climate variables: rainfall and temperature (January temperature or heating degree days). ${ }^{24}$ The independent variables in the employment density regressions are shares of employment in the various one-digit sectors of the economy. This implicitly assumes that agglomeration economies, if they exist, are captured within the one-digit industries. Urban specialization in different industries will affect overall employment densities since land intensities are likely to differ across these industries.

Tables 7 and 8 provide descriptive statistics of these variables for cities and metropolitan areas. ${ }^{25}$ The data indicate a marked decline in employment and population densities for the samples of cities and metropolitan areas over this period. For cities, the average employment and population densities of cities increased from 2667 and 6536 persons per mile to 1800 and 3777 respectively between 1950 and 1990. For metropolitan areas, population density fell from 513 persons per mile to 397 but employment density remained relatively constant. The shares of single-detached housing in cities and metropolitan areas increased slightly over time. On the other hand, the industrial structures of cities and metropolitan areas changed noticeably over time as economic structures shifted away from manufacturing into various services.

24 A heating degree day is a measure of energy required for heating buildings. One heating degree is accumulated for each whole degree that the mean daily temperature is below 65 degrees.

25 The 1990 metropolitan area data use MSA's rather than the CMSA's used in Table 5. 
The results of the monocentric city equation (1) are reported in Table $9 .^{26}$ The regression estimates suggest that the growth in automobile use is highly correlated with growth in singledetached housing. In 1950, cities and metropolitan areas with higher automobile registration rates had a significantly higher share of their housing stock in single-detached housing. In 1990, cities with higher percentages of commuters that used public transportation (inverse of automobile use) had a significantly lower share of single-detached housing whereas, for metropolitan areas, those with higher shares of commuters that used automobiles, trucks or vans, had a significantly higher share of single-detached or owner occupied housing. On the other hand, the income variables provided differing results. In 1950, median income was negatively correlated with singledetached housing for cities and metropolitan areas, the latter with statistical significance. ${ }^{27}$ In 1990, as predicted by the monocentric city model, income per capita was positively correlated with single-detached housing for cities and metropolitan areas, the former with statistical significance. In 1950, the cities and metropolitan areas in the New England and Middle Atlantic regions had significantly lower percentages of single-detached housing than those in other

26 Since automobile registration data are unavailable for all cities and metropolitan areas, the monocentric city model was estimated using a slightly smaller sample for 1950 .

27 There are numerous potential reasons why the income variables exhibit differing results. First, Wheaton (1977) shows that incomes can either cause higher or lower densities depending upon the relative income elasticities for land and commuting costs. If marginal costs of commuting increases with income, then higher incomes may cause households to live near the city center. Moreover, White $(1976,1988)$ demonstrates that when employment is decentralized and not concentrated in the city center, residential location and incomes may not be monotonically correlated with distance from the city center. In particular, high income households may locate near the city center and also far away in the suburbs. Second, LeRoy and Sonstelie (1983) suggest that incomes and automobile ownership was highly correlated until quite recently. Third, the relatively poor results of the income variable may also be caused by the lack of information on this dimension using cross-sectional variation across cities. Margo (1992), using data based on a sample of household heads for 1950 , finds that almost half of suburbanization can be attributed to rising household incomes. 
regions. In 1990, the same was true for the New England and Middle Atlantic cities but not for their metropolitan areas.

The results of the instrumental variable (IV) estimations of population and employment densities are reported in Table 10 for cities and Table 11 for metropolitan areas. For estimating the population density equation, the instruments for employment density were the single-digit industry shares that proxy for agglomeration economies. For estimating the employment density equation, the instruments for population density were single-detached housing or owner-occupied housing (or proxies for incomes and transportation costs) and climate variables.

The IV regression estimates for population density indicate that ownership of singledetached or owner-occupied housing significantly contributed to lowering population density for cities but not for metropolitan areas. ${ }^{28}$ For cities in 1950 and 1990, a standard deviation increase in the percentage of single-detached housing led to a decline in population density by about $11 \%$. However, the disappointing result for metropolitan areas are likely to be caused by the reduction in data variation that comes from aggregating data up to metropolitan areas. For example, the St. Louis metropolitan area is composed of many cities, such as St. Louis City, Clayton, University City, and Webster Groves among others, which differ in their stocks of single-detached housing.

The data indicate that urban areas with better climates were more dense than those with poorer climates. Of the two climate variables, temperature tended to be more important. For both cities and metropolitan areas, higher winter temperatures or lower heating degree days

${ }^{28}$ Mieszkowski and Smith (1991) use data on housing lot sizes to examine the patterns of decentralization in Houston. They find that density per residential land use is quite uniform and that the differences in densities between the city and the suburbs were caused by the greater amount of vacant land available in the suburbs. Thus, variations in single-detached housing may do a poorer job in explaining metropolitan population density as compared to explaining city population density. 
contributed to greater population densities in 1950 and 1990, respectively. In 1950, less

precipitation significantly increased city densities. One potential interpretation of this finding is that climate and urban densities jointly increase the value of urban amenities. Accordingly to Glaeser, Kolko and Saiz (2000), two of the four critical urban amenities are the existence of a variety of services and consumer goods and climate. The regression results suggest that the value of dense urban amenities increase with warmer climate since residents can enjoy the rich dense urban amenities such as restaurants and theaters for more months of the year.

The IV regression estimates for employment density provide important clues as to the causes of industry agglomeration. ${ }^{29}$ The regression estimates suggest that specialization in agriculture contributed to a decline in employment density but that specialization in manufacturing activities sometimes contributed to an increase in employment density. For agriculture, a standard deviation in its share for cities in 1950 and for metropolitan areas in 1990 contributed to declines in employment densities of one and four percent, respectively. For manufacturing, a standard deviation in its share led to a five percent increase in employment density for cities in 1950, and a three percent increase in employment density of metropolitan areas in 1990.

${ }^{29}$ In the late nineteenth century, Adna Weber was fully aware that patterns of industrial concentration significantly influenced trends in U.S. urbanization. He wrote: "The extractive industries generally require the dispersion of the persons engaged therein. In particular, agriculture, the principal extractive industry, cannot be prosecuted by persons residing in large groups... The distributive industries, on the other hand, are distinctly centralizing in their effects upon the distribution of the population engaged in them. As methods of distribution have been improved and the distributive area enlarged, the tendency toward concentration has increased... Manufacturing industries also tend toward the concentration of population, and up to recent years manufacturing centers were coincident with commercial centers i.e., the great cities. Recently the equalization of transportation facilities and the excessive rents of great cities have caused the managers of a good many industries to abandon them as sites in favor of the suburb or small town." (see Weber (1899, 223-224)). 
The data analysis strongly demonstrates that specialization in transaction services, such as wholesale trade and FIRE (finance, insurance and real estate) contributed significantly to employment density whereas specialization in other services, such as retail trade, health services, professional services, and public administration, tended to significantly lower employment density. ${ }^{30}$ The regression estimates show that a standard deviation increase in a city's or a metropolitan area's share of wholesale trade increased employment density by two to three percent and a standard deviation increase in the share of FIRE increased employment density of between four to six percent. On the other hand, a standard deviation increase in the share of other services such as retail trade lowered employment density from two to five percentage points.

The instrumental variable regression estimates of the simultaneous equations indicate that it is important to treat both residential and firm location decisions as endogenous. The IV regression estimates indicate that population density greatly influenced employment density and vice versa. In addition, the estimates on cities suggest that population density had a stronger impact on employment density than the reverse. For cities, the elasticities of population on employment density were 1.07 and 0.96 for 1950 and 1990 respectively; on the other hand, the elasticity of employment on population density was 0.71 and 0.60 for 1950 and 1990

30 Since data on housing are unavailable for earlier periods, it is not possible to estimate the monocentric city model nor the simultaneous equation model. However, Kim (2000) provides estimates for the potential importance of agglomeration economies using a slightly different specification. In 1900, specialization in trade and transportation significantly contributed to an increase in the density of cities; in 1920, specialization in transportation and in clerical services contributed to an increase in density; in 1940, specialization in business services and government employment contributed to an increase in density. In all three years, specialization in agriculture led to a decline in urban density. In general, the regression results indicate that specialization in manufacturing did not contribute to an increase in density of cities. However, this result is likely to have been caused by problems of multicollinearity since city specialization in manufacturing and transportation sectors was highly correlated. 
respectively. The estimates on metropolitan areas were much more symmetrical. The impact of population on employment density was only slightly greater than the impact of employment on population densities. In general, these elasticities ranged from 0.9 to 1.0 .

The data on urban density presented in section II suggest that population density is positively correlated with the age of the city. For the 119 cities in the consistent sample for which initial incorporation dates are readily available, a simple regression of density on incorporation dates show that city age is significantly correlated with urban density in every decade between 1890 and 1990. What accounts for this correlation? In order to answer this question more fully, data on incorporation date were collected for 304 cities in 1950. The analysis of the data suggests that there are two potential explanations. One explanation is based on path dependence emphasized by Krugman and David. If urban agglomeration economies are important, then initial advantages are locked into those cities that achieve density at an earlier time period. The regression results also indicate the agglomeration economies that contribute to lock-in effects are likely to be in transaction services rather than in manufacturing. The other complementary explanation is based on the observation that housing is very durable. Glaeser and Gyourko (2001) show that the durability of housing plays a significant role in understanding the nature of urban decline. This paper suggests that durability of housing may also influence urban density over time. Older cities may be more dense since they are more likely to have a larger housing stock composed of very durable apartments rather than single detached houses.

IV. Conclusion

During the nineteenth and the twentieth centuries, the U.S. urban population grew significantly as the population shifted from rural to urban areas. The urban population in the U.S. 
increased as the population in existing urban areas increased or as rural areas were transformed into urban areas when new cities formed or when old cities annexed surrounding rural areas. This paper examines the spatial organization of economic activities in U.S. urban areas between the late nineteenth and the twentieth centuries. This paper finds that between the late nineteenth and the mid-twentieth centuries, economic activities became more densely organized in urban areas despite the fact that large tracts of rural areas were annexed into existing urban areas. However, during the second half of the twentieth century, urban density declined substantially as the growth of urban population slowed and as urban boundaries continued to radiate into surrounding rural areas.

The analysis of cross-sectional data on the density of cities and metropolitan areas suggest that the variation in employment and population densities can be explained by models of city formation and the monocentric city model. The examination of employment density shows that urban specialization in economic activities related to facilitating market transactions, such as in wholesale trade, finance, insurance and real estate, was highly correlated with employment density. On the other hand, urban specialization in consumer service sectors, such as in retail trade, health, professional and other services, was negatively correlated with employment density. Urban specialization in manufacturing appears to have contributed to urban density in differing ways over time. The analysis of population density suggests that lower transportation costs, as proxied by the growing use of automobiles, and higher incomes appear to have contributed to the decline in population density as households increased their demand for larger housing. Finally, the regression estimates show that firm location and household residential decisions greatly influenced each other. 
While it is difficult to explain the long-run trends in urban density based on crosssectional data analysis, the two sets of regressions over two different time periods may provide some important clues. During the late nineteenth and the mid-twentieth centuries, the data suggest that urban density increased as the forces of agglomeration economies in employment, particularly in transaction services, outweighed the forces of population dispersion. During this period, the advances in skyscraper technology, greatly increased employment density. However, households mitigated this trend in two ways. Households demanded larger housing further away from the central business district in existing urban areas thereby increasing the boundaries of these areas. In addition, households migrated to less developed urban areas to consume larger housing since the opportunity costs of commuting by automobiles were lower in these newer areas. ${ }^{31}$

During the second half of the twentieth century, urban density declined dramatically. While agglomeration economies in transaction services continued to contribute to employment density, other forces contributed to its dispersion. The data indicate that there were significant spatial agglomeration dis-economies in the provision of consumer services and that the growth of this sector over time may have contributed to a significant decline in overall employment density. In addition, as household incomes rose and as transportation costs fell, population density fell as households continued to demand larger housing in the form of single-detached houses. Although household residential decisions had an increasingly larger impact on the location of employment than the reverse, the sharp decline in densities of urban areas in this period was made possible by

31 Thus, the density of the consistent sample of cities which represent established cities rose whereas the density of the full sample of cities remained relatively flat. 
the strong interaction of household and firm location decisions that greatly re-enforced each others' trends.

Scholars have traced the origins of suburbanization to the early nineteenth century, but the process of suburbanization has been far from uniform. The data on urban land area as well as various studies on urban density gradients indicate that population and employment have been steadily radiating away from city centers over time. However, data on average density show that even as the boundaries of cities and metropolitan areas expanded, these urban areas became increasingly dense between the late nineteenth and the mid-twentieth centuries. Indeed, for many urban planners, this era is often identified with the golden years of American cities. However, since the second half of the twentieth century, the process of suburbanization has taken on an entirely different character. During this period, the ever expanding urban boundaries have been accompanied by significant declines in the average densities of cities and metropolitan areas. Yet, whether this suburban sprawl represents a better form of living and working as argued by many economists or whether it represents a loss of American civic life as claimed by many urban planners remains an important topic to be explored. ${ }^{32}$

32 For many urban planners, the years between the late nineteenth and the early twentieth centuries, which coincided with the City Beautiful Movement, were the glory years of the city and the downtown. On the other hand, the late twentieth century suburban sprawl is identified with the loss of urban civic amenities. See Duany, Plater-Zyberk, and Speck (2000). 
Table 1

Population and Employment Densities of Cities, 1890-1990

$\begin{array}{llllll} & \begin{array}{l}\text { Number of } \\ \text { Cities }\end{array} & \begin{array}{l}\text { Average } \\ \text { Population }\end{array} & \begin{array}{l}\text { Average } \\ \text { Area } \\ \text { (sq. miles) }\end{array} & \begin{array}{l}\text { Average } \\ \text { Population } \\ \text { Density Density }\end{array} & \begin{array}{l}\text { Average } \\ \text { Employment }\end{array} \\ 1890 & 122 & 113835 & 16.7 & 7648 & - \\ 1900 & 160 & 123243 & 20.2 & 7377 & 3147 \\ 1910^{*} & 184 & 148442 & 23.1 & 7176 & - \\ 1920^{*} & 252 & 145966 & 20.9 & 7597 & - \\ 1930^{*} & 310 & 152890 & 21.9 & 7366 & - \\ 1940 & 412 & 128051 & 19.2 & 6742 & - \\ 1950 & 481 & 128811 & 19.5 & 6536 & 2667 \\ 1960 & 673 & 112400 & 22.8 & 5340 & - \\ 1970 & 835 & 104785 & 28.5 & 4673 & 1870 \\ 1980 & 944 & 97756 & 32.8 & 3998 & - \\ 1990 & 1068 & 98108 & 34.9 & 3783 & 1800\end{array}$

Note: The data, except for years 1910-1930, are for cities with population over 25,000. In 1890, two cities were omitted due to lack of data on land area. Cities in Alaska and Hawaii are excluded.

*Data for 1910-1930 are for cities with population over 30,000.

Sources: Social Statistics of Cities, 1890; Census of Population, 1900; Financial Statistics of Cities, 1910, 1920, 1930; County and City Data Book, 1949, 1952, 1962, 1972, 1982, 1988, 1994. 
Table 2

Population Density of Cities by Region, 1890-1990

$\begin{array}{lllllllllll}1890 & 1900 & 1910 & 1920 & 1930 & 1940 & 1950 & 1960 & 1970 & 1980 & 1990\end{array}$

New England

Number

$\begin{array}{lllllllllll}23 & 30 & 32 & 40 & 45 & 61 & 55 & 64 & 68 & 69 & 71\end{array}$

$\begin{array}{llllllllllll}\text { Area } & 17.1 & 18.6 & 21.1 & 18.9 & 18.7 & 19.4 & 21.7 & 21.9 & 22.3 & 22.4 & 22.8\end{array}$

$\begin{array}{llllllllllll}\text { Density } & 5899 & 5645 & 6057 & 6712 & 6958 & 5987 & 5755 & 4987 & 4778 & 4461 & 4341\end{array}$

Middle Atlantic

$\begin{array}{llllllllllll}\text { Number } & 32 & 39 & 45 & 56 & 64 & 80 & 82 & 94 & 103 & 92 & 82\end{array}$

$\begin{array}{llllllllllll}\text { Area } & 15.0 & 20.2 & 18.9 & 17.0 & 17.5 & 15.6 & 15.2 & 14.9 & 14.3 & 15.6 & 17.8\end{array}$

$\begin{array}{llllllllllll}\text { Density } & 10515 & 10409 & 10839 & 12208 & 11723 & 10593 & 10832 & 9504 & 9002 & 8598 & 8212\end{array}$

East North Central

$\begin{array}{llllllllllll}\text { Number } & 21 & 32 & 37 & 61 & 81 & 101 & 115 & 156 & 192 & 206 & 214 \\ \text { Area } & 18.9 & 17.8 & 19.9 & 17.5 & 18.0 & 16.2 & 15.7 & 16.9 & 20.2 & 21.8 & 22.8 \\ \text { Density } & 6760 & 6511 & 6514 & 6751 & 7100 & 6619 & 6584 & 5619 & 5007 & 4060 & 3691\end{array}$

West North Central

$\begin{array}{llllllllllll}\text { Number } & 14 & 18 & 18 & 20 & 21 & 29 & 39 & 53 & 74 & 78 & 86\end{array}$

$\begin{array}{llllllllllll}\text { Area } & 24.6 & 26.1 & 30.0 & 30.0 & 30.4 & 24.4 & 21.3 & 23.7 & 29.0 & 34.2 & 35.2\end{array}$

$\begin{array}{llllllllllll}\text { Density } & 4881 & 4201 & 4298 & 4544 & 4642 & 4588 & 4675 & 4133 & 3209 & 2480 & 2369\end{array}$

South Atlantic

\begin{tabular}{|c|c|c|c|c|c|c|c|c|c|c|c|}
\hline Number & 10 & 11 & 17 & 29 & 34 & 47 & 60 & 77 & 92 & 116 & 141 \\
\hline Area & 9.5 & 12.7 & 13.8 & 18.8 & 17.9 & 15.1 & 15.3 & 22.7 & 39.5 & 42.7 & 43.2 \\
\hline Density & 11605 & 11433 & 8296 & 7809 & 6461 & 6120 & 5703 & 4296 & 3554 & 3228 & 3019 \\
\hline
\end{tabular}

East South Central

$\begin{array}{llllllllllll}\text { Number } & 7 & 11 & 11 & 10 & 13 & 20 & 27 & 38 & 41 & 46 & 47 \\ \text { Area } & 6.5 & 6.7 & 14.0 & 17.8 & 22.0 & 16.7 & 19.0 & 28.4 & 47.0 & 58.9 & 64.9 \\ \text { Density } & 9795 & 10794 & 8333 & 6723 & 5798 & 5692 & 5356 & 3754 & 2705 & 1882 & 1574\end{array}$

West South Central

$\begin{array}{llllllllllll}\text { Number } & 6 & 7 & 9 & 15 & 21 & 29 & 39 & 63 & 77 & 89 & 104\end{array}$

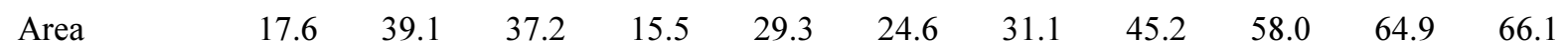

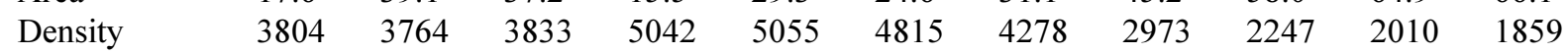

Mountain

$\begin{array}{llllllllllll}\text { Number } & 2 & 4 & 4 & 7 & 8 & 11 & 18 & 31 & 44 & 61 & 71 \\ \text { Area } & 32.1 & 35.3 & 31.0 & 22.3 & 20.7 & 17.5 & 18.3 & 23.8 & 30.5 & 48.1 & 60.2 \\ \text { Density } & 3700 & 4938 & 4259 & 4210 & 4728 & 4661 & 4501 & 4035 & 3238 & 2613 & 2266\end{array}$

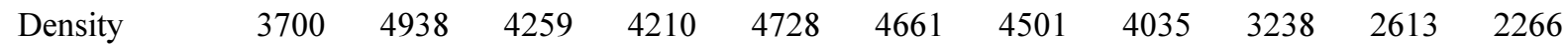

Pacific

$\begin{array}{llllllllllll}\text { Number } & 7 & 8 & 11 & 15 & 23 & 34 & 46 & 97 & 144 & 87 & 252\end{array}$

$\begin{array}{llllllllllll}\text { Area } & 15.8 & 26.6 & 55.4 & 54.0 & 45.7 & 34.7 & 28.6 & 23.2 & 23.8 & 24.0 & 23.7\end{array}$

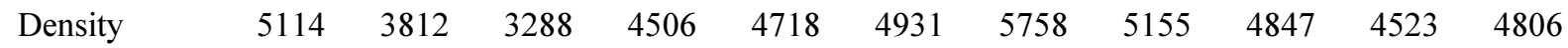

Sources: See Table 1. 
Table 3

Population Density of Cities, 1890-1990

(Data are for consistent set of 119 Cities)

\begin{tabular}{|c|c|c|c|c|c|c|}
\hline & Average & Average & Average & Avera & Grov & h Rates \\
\hline & & (sq. miles) & Density Pop. & Land & Densi & \\
\hline 1890 & 117124 & 19.1 & 7203 & & & \\
\hline 1900 & 154266 & 23.9 & 7762 & 0.25 & 0.20 & 0.05 \\
\hline 1910 & 206711 & 29.5 & 7626 & 0.30 & 0.28 & 0.02 \\
\hline 1920 & 258182 & 32.5 & 8697 & 0.22 & 0.10 & 0.13 \\
\hline 1930 & 311661 & 36.8 & 8751 & 0.15 & 0.12 & 0.02 \\
\hline 1940 & 324865 & 37.2 & 8751 & 0.03 & 0.01 & 0.01 \\
\hline 1950 & 359297 & 40.6 & 8876 & 0.08 & 0.07 & 0.01 \\
\hline 1960 & 371478 & 50.8 & 7660 & 0.04 & 0.19 & -0.15 \\
\hline 1970 & 375600 & 64.2 & 6744 & -0.01 & 0.15 & -0.16 \\
\hline 1980 & 344608 & 69.9 & 5890 & -0.10 & 0.06 & -0.16 \\
\hline 1990 & 350320 & 72.8 & 5647 & 0.01 & 0.05 & -0.04 \\
\hline
\end{tabular}

Sources: Social Statistics of Cities, 1890; Census of Population, 1900; Financial Statistics of Cities, 1910, 1920, 1930; County and City Data Book, 1949, 1952, 1962, 1972, 1982, 1988, 1994. 
Table 4

Population Density of Metropolitan Districts, 1910-1940

\begin{tabular}{|c|c|c|c|c|}
\hline & $\begin{array}{l}\text { Number of } \\
\text { Metro Areas }\end{array}$ & $\begin{array}{l}\text { Average } \\
\text { Population }\end{array}$ & $\begin{array}{l}\text { Average } \\
\text { Land Area } \\
\text { (sq. miles) }\end{array}$ & $\begin{array}{l}\text { Average Population } \\
\text { Density }\end{array}$ \\
\hline 1910 & 30 & 720852 & 318.8 & 1909.9 \\
\hline 1920 & 40 & 719437 & 341.0 & 1733.3 \\
\hline 1930 & 65 & 642670 & 402.9 & 1188.7 \\
\hline 1940 & 92 & 512243 & 346.1 & 1139.8 \\
\hline $1910^{*}$ & 30 & 720852 & 318.8 & 1909.9 \\
\hline $1920 *$ & 30 & 884581 & 347.7 & 2041.7 \\
\hline $1930 *$ & 30 & 1178974 & 549.5 & 1666.5 \\
\hline $1940 *$ & 30 & 1252307 & 577.0 & 1678.4 \\
\hline
\end{tabular}


Table 5

Population Density of Metropolitan Areas, 1940-1990

$\begin{array}{llllll} & \begin{array}{l}\text { Number of } \\ \text { Metro Areas }\end{array} & \begin{array}{l}\text { Average } \\ \text { Population }\end{array} & \begin{array}{l}\text { Average } \\ \text { Land Area } \\ \text { (sq. miles) }\end{array} & \begin{array}{l}\text { Average } \\ \text { Population } \\ \text { Density Density }\end{array} & \begin{array}{l}\text { Average } \\ \text { Employment }\end{array} \\ 1940 & 156 & 439143 & 1138 & 386.9 & - \\ 1950 & 170 & 498325 & 1226 & 513.1 & 204.2 \\ 1960 & 212 & 632774 & 1463 & 589.4 & - \\ 1970 & 243 & 573737 & 1597 & 539.7 & - \\ 1980 & 305 & 558993 & 1888 & 383.1 & - \\ 1990 & 281 & 686860 & 2067 & 288.0 & 146.8\end{array}$

Sources: County and City Data Book, 1949, 1952, 1962, 1972. State and Metropolitan Area Data Book, 1982, 1991. 
Table 6

Population Density of Metropolitan Areas, 1940-1980

(Data are for consistent set of 149 metro areas)

\begin{tabular}{llllllll} 
& $\begin{array}{l}\text { Average } \\
\text { Population }\end{array}$ & $\begin{array}{l}\text { Average } \\
\text { Land Area } \\
\text { (sq. miles) }\end{array}$ & $\begin{array}{l}\text { Average Population } \\
\text { Density }\end{array}$ & \multicolumn{3}{c}{ Average Growth Rates } \\
1940 & 448495 & 1161 & 389.6 & Pop. & Land & Density \\
1950 & 545626 & 1216 & 492.2 & 0.23 & -0.01 & 0.23 \\
1960 & 664643 & 1336 & 547.0 & 0.25 & 0.10 & 0.15 \\
1970 & 783523 & 1589 & 500.9 & 0.17 & 0.23 & -0.06 \\
1980 & 885569 & 2100 & 442.1 & 0.19 & 0.31 & -0.12
\end{tabular}

Sources: County and City Data Book, 1949, 1952, 1962, 1972. State and Metropolitan Area Data Book, 1982, 1991. 
Table 7

Descriptive Statistics of Cities, 1950-1990

Mean SD $\quad$ Minimum Maximum Number

1950

\begin{tabular}{|c|c|c|c|c|c|}
\hline Population density & 6535.9 & 4856.6 & 436.6 & 50676.0 & 481 \\
\hline Detached dwelling & $52.1 \%$ & 19.2 & 0.9 & 88.2 & 481 \\
\hline Temperature (Jan.) & $33.3^{\circ}$ & 11.6 & 3.5 & 70.0 & 481 \\
\hline Precipitation & $36.8^{\prime \prime}$ & 11.2 & 6.0 & 63.1 & 481 \\
\hline $\begin{array}{l}\text { Employment density } \\
\text { (percent of labor) }\end{array}$ & 2666.8 & 2120.9 & 164.7 & 21597.0 & 481 \\
\hline Agriculture & $1.6 \%$ & 2.8 & 0.1 & 32.7 & 481 \\
\hline Manufacturing & $29.9 \%$ & 15.4 & 3.7 & 67.9 & 481 \\
\hline Transportation & $8.8 \%$ & 4.0 & 1.9 & 41.8 & 481 \\
\hline Retail trade & $17.7 \%$ & 5.4 & 3.3 & 44.2 & 481 \\
\hline Wholesale trade & $4.1 \%$ & 1.7 & 0.8 & 9.8 & 481 \\
\hline Detached dwelling & $49.5 \%$ & 19.4 & 0.90 & 88.2 & 396 \\
\hline Median income & 3431.7 & 548.6 & 1587 & 6489 & 396 \\
\hline Auto registration & 0.24 & 0.13 & 0.06 & 2.23 & 396 \\
\hline
\end{tabular}

(per capita)

1990

$\begin{array}{lrlccc}\text { Population density } & 3777.2 & 3439.3 & 46.5 & 44625.0 & 1067 \\ \text { Detached dwelling } & 55.1 \% & 16.4 & 1.0 & 93.9 & 1067 \\ \text { Temperature (HDs) } & 4263.7 & 2225.6 & 139.0 & 9818.0 & 1067 \\ \text { Precipitation } & 33.7 " & 14.3 & 2.7 & 66.4 & 1067 \\ \text { Income per capita } & \$ 14836 & 5010.7 & 5561 & 55463 & 1067 \\ \text { Public transportation } & 3.8 \% & 5.44 & 0.00 & 53.4 & 1067 \\ & & & & & \\ \text { Employment density } & 1800.0 & 1675.8 & 19.1 & 21192.0 & 1067 \\ \text { (percent of labor) } & & & & & \\ \text { Manufacturing } & 17.3 \% & 7.5 & 3.4 & 43.5 & 1067 \\ \text { Trade } & 22.6 \% & 3.0 & 11.3 & 32.5 & 1067 \\ \text { FIRE } & 7.1 \% & 2.6 & 1.8 & 21.5 & 1067 \\ \text { Health Services } & 8.8 \% & 2.6 & 2.6 & 26.2 & 1067 \\ \text { Public Adm. } & 4.7 \% & 3.2 & 1.0 & 31.8 & 1067\end{array}$

Sources: County and City Data Book, 1949, 1952, 1994. 
Table 8

Descriptive Statistics of Metropolitan Areas, 1950-1990

Mean SD Minimum Number

1950

\begin{tabular}{|c|c|c|c|c|c|}
\hline Population density & 513.1 & 570.6 & 14.0 & 3466.5 & 170 \\
\hline Detached dwelling & $61.8 \%$ & 14.8 & 23.9 & 86.3 & 170 \\
\hline Temperature (Jan.) & $34.4^{\circ}$ & 11.3 & 9.7 & 68.3 & 170 \\
\hline Precipitation & $36.8^{\prime \prime}$ & 10.6 & 7.8 & 62.4 & 170 \\
\hline $\begin{array}{l}\text { Employment density } \\
\text { (percent of labor) }\end{array}$ & 204.2 & 235.9 & 4.6 & 1568.0 & 170 \\
\hline Agriculture & $4.8 \%$ & 4.0 & 0.6 & 23.3 & 170 \\
\hline Manufacturing & $28.5 \%$ & 13.7 & 5.8 & 59.8 & 170 \\
\hline Transportation & $8.6 \%$ & 3.6 & 3.2 & 36.8 & 170 \\
\hline \multicolumn{6}{|l|}{ Retail and } \\
\hline Wholesale trade & $20.7 \%$ & 3.4 & 10.6 & 29.7 & 170 \\
\hline Detached dwelling & $63.5 \%$ & 13.6 & 23.9 & 86.3 & 138 \\
\hline Median income & 3254.9 & 458.0 & 2258.0 & 4262.0 & 138 \\
\hline Auto registration & 0.19 & 0.04 & 0.12 & 0.29 & 138 \\
\hline
\end{tabular}

(per capita)

1990

\begin{tabular}{|c|c|c|c|c|c|}
\hline Population density & 397.4 & 851.3 & 11.5 & 11844.0 & 321 \\
\hline Owner Occupied & $65.1 \%$ & 6.4 & 32.5 & 80.3 & 321 \\
\hline Temperature (HDs) & 4516.1 & 2146.6 & 200.0 & 9818.0 & 321 \\
\hline Precipitation & $37.4^{\prime \prime}$ & 13.3 & 3.17 & 65.7 & 321 \\
\hline Household Income & $\$ 36218.0$ & 7332.7 & 21202.0 & 91156.0 & 321 \\
\hline $\begin{array}{l}\text { Commute by auto, } \\
\text { van or truck }\end{array}$ & $89.7 \%$ & 5.2 & 39.6 & 95.8 & 321 \\
\hline $\begin{array}{l}\text { Employment density } \\
\text { (percent of labor) }\end{array}$ & 191.3 & 413.4 & 5.3 & 5756.2 & 321 \\
\hline Agriculture & $3.2 \%$ & 2.7 & 0.4 & 18.9 & 321 \\
\hline Manufacturing & $17.4 \%$ & 7.3 & 4.3 & 46.3 & 321 \\
\hline Wholsale trade & $4.2 \%$ & 1.2 & 1.7 & 11.6 & 321 \\
\hline Retail trade & $18.0 \%$ & 2.1 & 12.6 & 26.0 & 321 \\
\hline FIRE & $6.1 \%$ & 2.0 & 2.7 & 16.3 & 321 \\
\hline Professional Services & $24.2 \%$ & 4.7 & 4.8 & 48.7 & 32 \\
\hline
\end{tabular}

Sources: County and City Data Book, 1949, 1952; Census of Population and Housing, Supplementary Reports, 1990. 
Table 9

Determinants of Single Detached Housing, 1950-1990

1950

Constant

Median income

Automobile registration

Regional dummies

New England

Middle Atlantic

Midwest

South

Adj $R^{2}$

$\mathrm{N}$
Cities

Single

Detached

Housing

(percent)

$62.66^{* * *}$

(9.88)

$-0.0017$

(1.09)

$20.30 * * *$

(3.43)

$-28.36^{* * *}$

(9.28)

$-32.28 * * *$

(11.66)

$-3.53$

(1.43)

$-5.39 *$

(1.86)

0.489

396
Metropolitan Areas

Single

Detached

Housing

(percent)

$78.18^{* * *}$

(8.06)

$-0.013 * * *$

(5.51)

$180.08 * * *$

(5.34)

$-18.46^{* *}$

(2.45)

$-20.98 * * *$

(6.05)

$-2.85$

(0.99)

$-1.93$

(0.53)

0.490

138

* Significant at the 10 percent level.

** Significant at the 5 percent level.

*** Significant at the 1 percent level.

Sources: See Table 8.

Note: The sample size is reduced due to the lack of automobile registration data for some cities. 
Table 9 - continued

Determinants of Single-Detached Housing, 1950-1990

1990

Cities

Metropolitan Areas

\begin{tabular}{|c|c|c|c|}
\hline & $\begin{array}{l}\text { Single } \\
\text { Detached } \\
\text { Housing } \\
\text { (percent) }\end{array}$ & $\begin{array}{l}\text { Single } \\
\text { Detached } \\
\text { Housing } \\
\text { (percent) }\end{array}$ & $\begin{array}{l}\text { Owner } \\
\text { Occupied } \\
\text { Housing } \\
\text { (percent) }\end{array}$ \\
\hline Constant & $\begin{array}{l}55.95 * * * \\
(37.46)\end{array}$ & $\begin{array}{l}-0.33^{*} \\
(1.71)\end{array}$ & $\begin{array}{l}-0.13^{* *} \\
(2.42)\end{array}$ \\
\hline Income per capita & $\begin{array}{l}2.72 * * * \\
(3.33)\end{array}$ & $\begin{array}{l}0.0014 \\
(0.10)\end{array}$ & $\begin{array}{l}0.0027 \\
(0.69)\end{array}$ \\
\hline Public transportation & $\begin{array}{l}-1.28 * * * \\
(15.6)\end{array}$ & - & - \\
\hline $\begin{array}{l}\text { Means of transportation to } \\
\text { work: car, truck or van } \\
\text { (percent) }\end{array}$ & - & $\begin{array}{l}1.055^{* * * *} \\
(5.32)\end{array}$ & $\begin{array}{l}0.832 * * * \\
(14.95)\end{array}$ \\
\hline \multicolumn{4}{|l|}{ Regional Dummies } \\
\hline New England & $\begin{array}{l}-13.97 * * * \\
(8.06)\end{array}$ & $\begin{array}{l}-0.07^{*} \\
(1.68)\end{array}$ & $\begin{array}{l}0.009 \\
(0.72)\end{array}$ \\
\hline Middle Atlantic & $\begin{array}{l}-9.13 * * * \\
(5.20)\end{array}$ & $\begin{array}{l}-0.12 \\
(0.36)\end{array}$ & $\begin{array}{l}0.077^{* * *} \\
(8.05)\end{array}$ \\
\hline Midwest & $\begin{array}{l}6.06^{* * * *} \\
(5.79)\end{array}$ & $\begin{array}{l}0.04 \\
(1.43)\end{array}$ & $\begin{array}{l}0.044 * * * \\
(5.44)\end{array}$ \\
\hline South & $\begin{array}{l}0.06 \\
(0.05)\end{array}$ & $\begin{array}{l}0.003 \\
(0.10)\end{array}$ & $\begin{array}{l}0.011 \\
(1.45)\end{array}$ \\
\hline $\operatorname{Adj} R^{2}$ & 0.369 & 0.110 & 0.475 \\
\hline $\mathrm{N}$ & 1067 & 321 & 321 \\
\hline
\end{tabular}

* Significant at the 10 percent level. ** Significant at the 5 percent level.

*** Significant at the 1 percent level.

Sources: See Table 8. 
Table 10

IV Regressions for Population and Employment Densities of U.S. Cities, 1950-1990

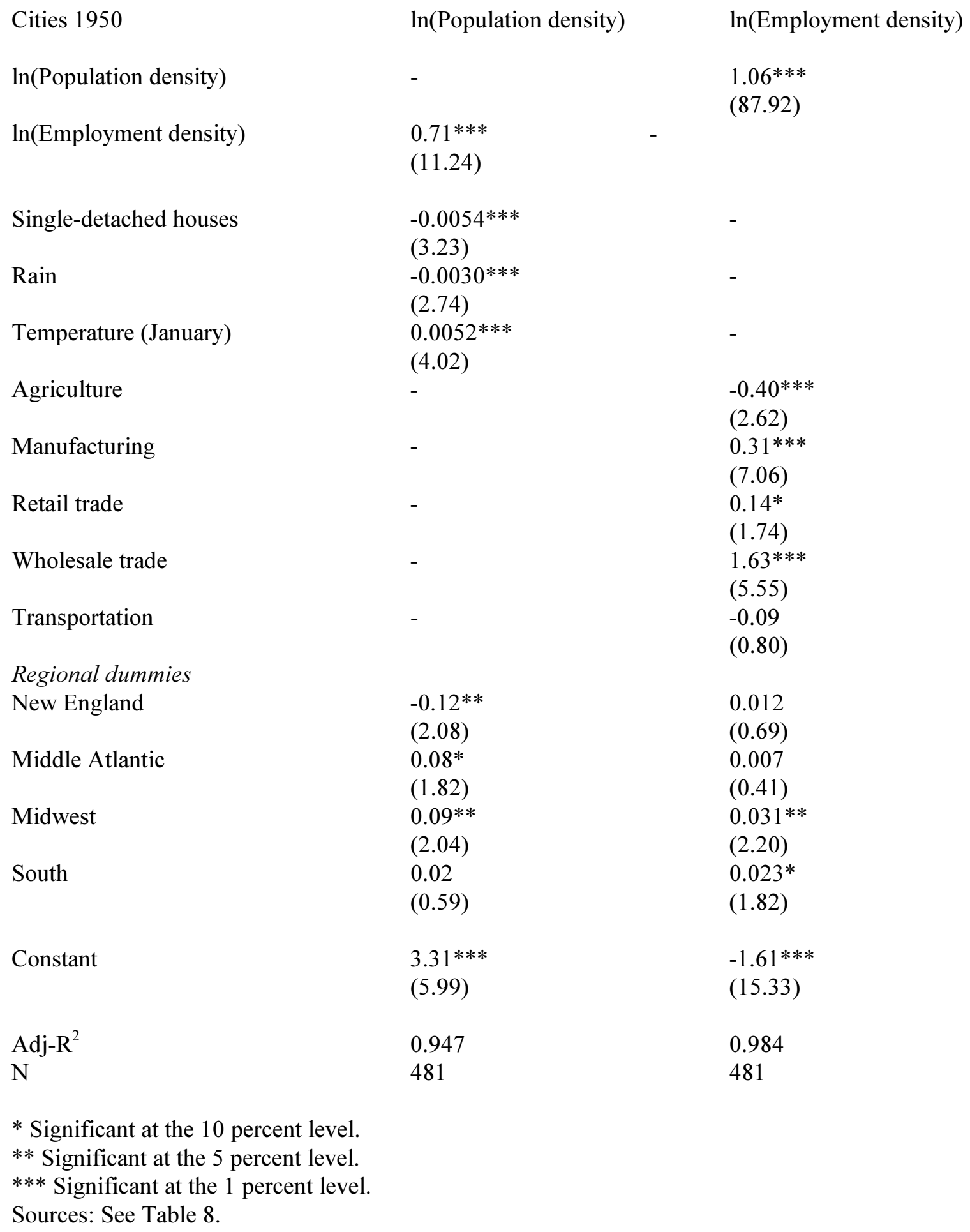


Table 10 - continued

IV Regressions for Population and Employment Densities of U.S. Cities, 1950-1990

\begin{tabular}{|c|c|c|}
\hline Cities 1990 & $\ln ($ Population density) & $\ln ($ Employment density) \\
\hline $\ln$ (Population density) & - & $\begin{array}{l}0.96^{* * *} \\
(85.98)\end{array}$ \\
\hline $\ln$ (Employment density) & $\begin{array}{l}0.60 * * * \\
(15.06)\end{array}$ & \\
\hline Single-detached houses & $\begin{array}{l}-0.007 * * * \\
(7.66)\end{array}$ & - \\
\hline Rain & $\begin{array}{l}0.00016 \\
(0.17)\end{array}$ & - \\
\hline Temperature (Heating degrees) & $\begin{array}{l}-0.513^{* * *} \\
(7.33)\end{array}$ & - \\
\hline Manufacturing & - & $\begin{array}{l}-0.036 \\
(0.60)\end{array}$ \\
\hline Trade (Retail and Wholesale) & - & $\begin{array}{l}-0.846^{* * *} \\
(6.37)\end{array}$ \\
\hline FIRE & - & $\begin{array}{l}2.503 * * * \\
(16.37)\end{array}$ \\
\hline Health & - & $\begin{array}{l}-1.816^{* * *} \\
(11.89)\end{array}$ \\
\hline Public Adm. & - & $\begin{array}{l}-0.990^{* * *} \\
(7.69)\end{array}$ \\
\hline \multicolumn{3}{|l|}{ Regional dummies } \\
\hline New England & $\begin{array}{l}-0.030 \\
(0.64)\end{array}$ & $\begin{array}{l}0.053 * * * \\
(3.39)\end{array}$ \\
\hline Middle Atlantic & $\begin{array}{l}0.252^{* * *} \\
(5.48)\end{array}$ & $\begin{array}{l}0.020 \\
(1.22)\end{array}$ \\
\hline Midwest & $\begin{array}{l}0.140^{* * *} \\
(4.03)\end{array}$ & $\begin{array}{l}0.044 * * * \\
(4.40)\end{array}$ \\
\hline South & $\begin{array}{l}-0.219^{* * *} \\
(5.18)\end{array}$ & $\begin{array}{l}-0.018^{*} \\
(1.66)\end{array}$ \\
\hline Constant & $\begin{array}{l}4.26 * * * \\
(12.16)\end{array}$ & $\begin{array}{l}-0.67 * * * \\
(5.53)\end{array}$ \\
\hline $\operatorname{Adj}-R^{2}$ & 0.886 & 0.977 \\
\hline $\mathrm{N}$ & 1067 & 1067 \\
\hline
\end{tabular}


Table 11

IV Regressions for Population and Employment Densities of U.S. Metropolitan Areas, 1950-1990

Metro Areas 1950

$\ln ($ Population density) $\quad \ln ($ Employment density)

$\ln ($ Population density)

-

$1.031^{* * *}$

$\ln ($ Employment density)

$0.957 * * *$

(43.71)

(60.84)

Single-detached houses

$-0.084$

$(0.09)$

Rain

$-0.0003$

$(0.27)$

Temperature (January) $\quad 0.002^{*}$

(1.68)

Agriculture

$-$

0.247

(0.72)

Manufacturing

-

$-0.031$

$(0.28)$

Trade (Retail and Wholesale)

-

$-0.855^{* * *}$

(2.86)

FIRE

-

$2.70 * * *$

(3.78)

Professional Services

$-$

$-0.365$

(1.09)

$\begin{array}{rr}- & -0.217 \\ & (0.99)\end{array}$

Transportation

Regional dummies

New England

$-0.010$

0.059

$(0.23)$

$-0.048$

(1.50)

Middle Atlantic

(1.27)

$0.094 * * *$

(3.12)

Midwest

$-0.053$

(1.61)

South

$-0.025$

$0.104^{* * *}$

(4.06)

(0.83)

0.041 *

(1.79)

Constant

$1.146^{* * *}$

$-1.068^{* * *}$

(9.36)

(6.56)

$\operatorname{Adj}-R^{2}$

0.993

0.961

$\mathrm{N}$

170

170

* Significant at the 10 percent level.

** Significant at the 5 percent level.

*** Significant at the 1 percent level.

Sources: See Table 9. 
Table 11 - continued

IV Regressions for Population and Employment Densities of U.S. Metropolitan Areas, 1950-1990

Metro Areas 1990

$\ln ($ Population density) $\quad \ln ($ Employment density)

$\ln$ (Population density)

- $\quad 0.949^{* * *}$

$\ln ($ Employment density)

$0.896^{* * *}$

(33.8)

(55.36)

Owner-occupied houses (\%)

$-0.025$

$(0.15)$

Rain

0.0002

$(0.14)$

Temperature (Heating degrees)

$-0.00003 * * *$

(4.36)

Agriculture

$-$

Manufacturing

$-$

Wholesale trade

$-$

Retail trade

$-$

FIRE

Professional Services

$-$

$-$

$-1.572 * * *$

(3.13)

0.356

(1.64)

$1.884^{* *}$

(2.22)

$-2.376^{* * *}$

(4.20)

$2.209^{* * *}$

(2.99)

0.322

(1.32)

Regional dummies

New England

$0.13^{* *}$

0.050

(2.35)

0.084 *

(1.07)

Middle Atlantic

(1.72)

0.040

0.074 *

(1.11)

Midwest

(1.84)

0.020

0.018

(0.64)

South

(0.48)

$-0.030$

(1.18)

Constant

$1.366^{* * *}$

-0.372 *

(9.46)

(1.55)

$\operatorname{Adj}-R^{2}$

0.977

0.978

$\mathrm{N}$

321

321

* Significant at the 10 percent level.

** Significant at the 5 percent level.

*** Significant at the 1 percent level.

Sources: See Table 9. 
Figure 1

Density of Cities, 1890-1990

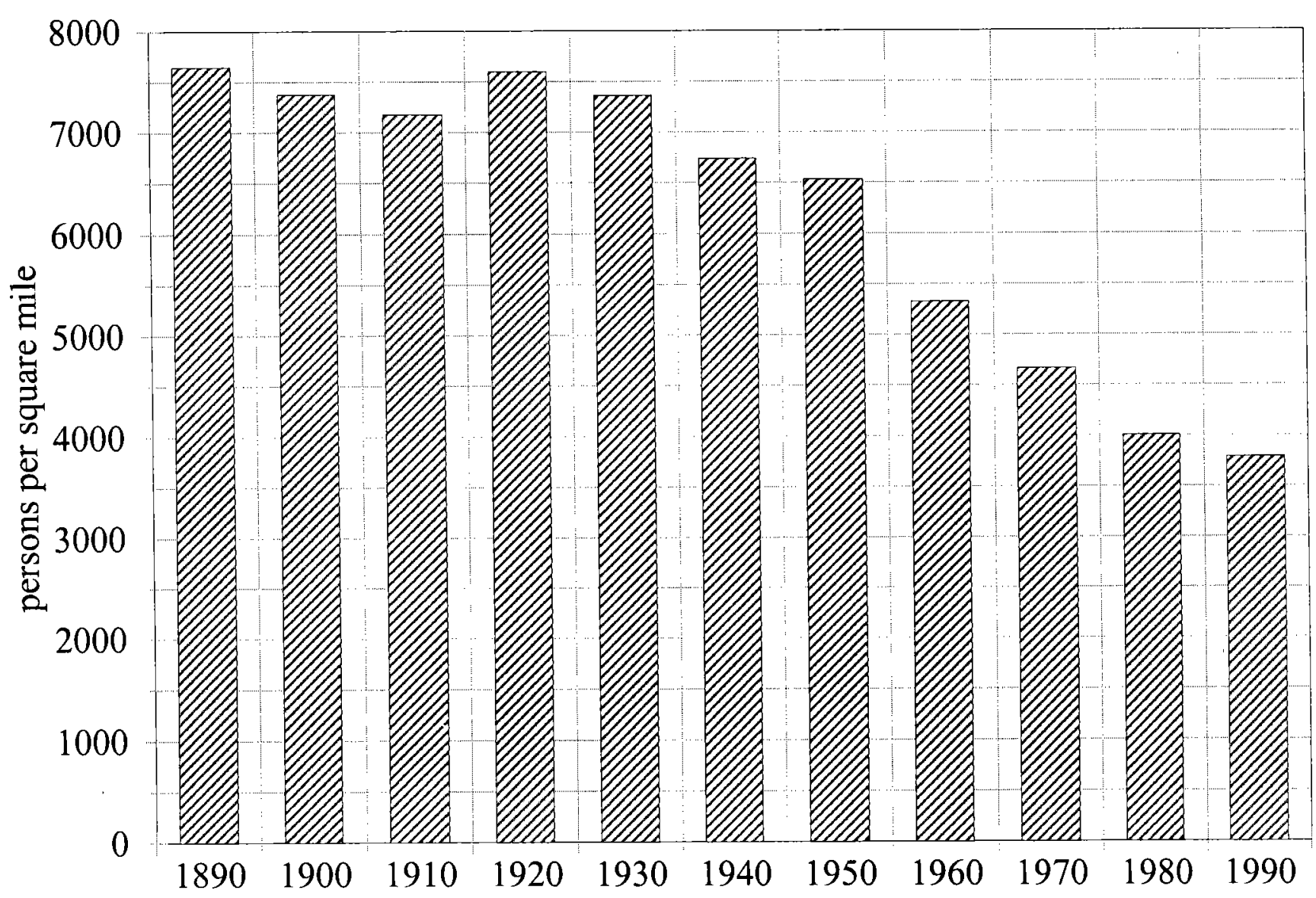


Figure 2

Density of Cities by Region, 1890-1990

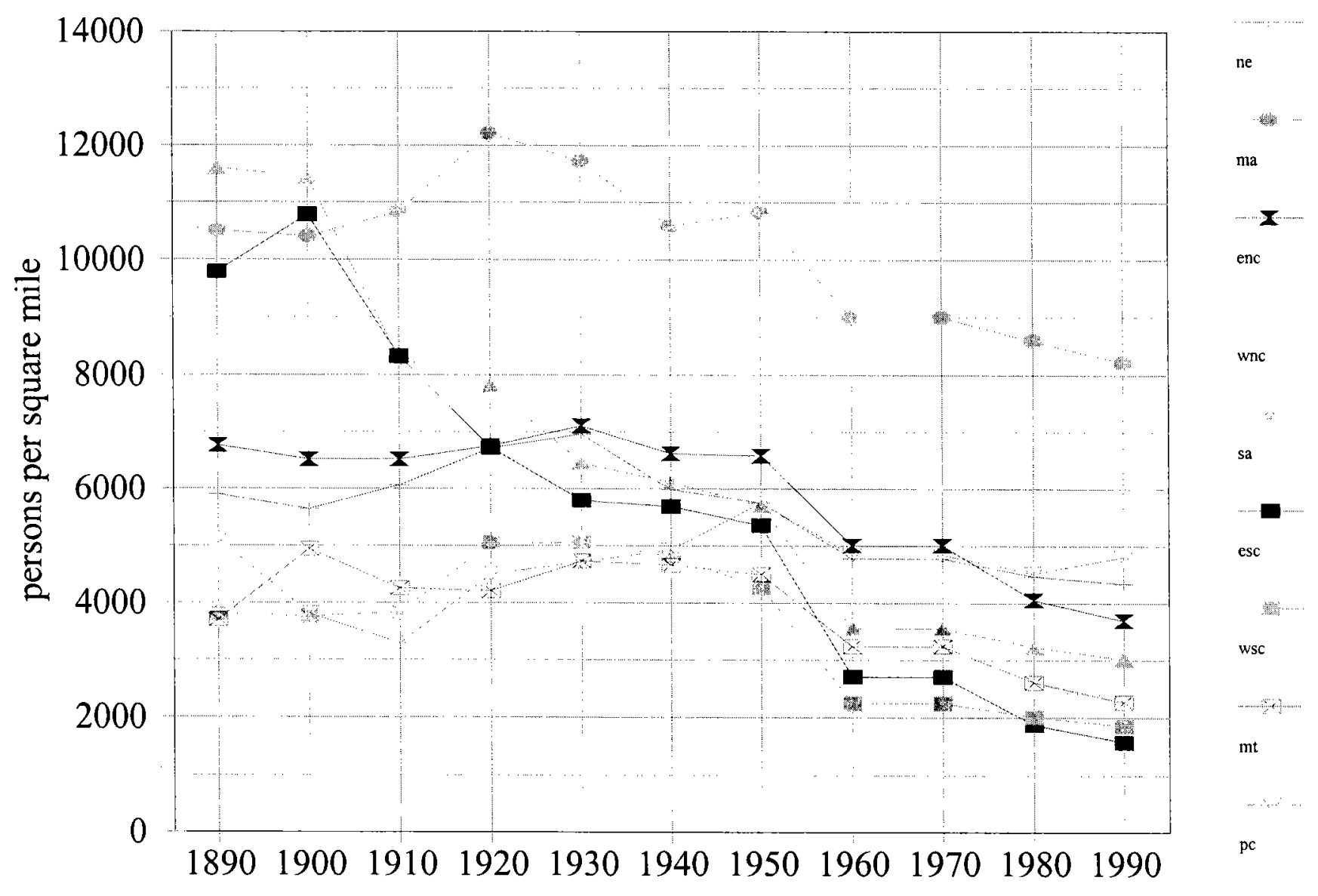


Figure 3

Density of Cities, 1890-1990

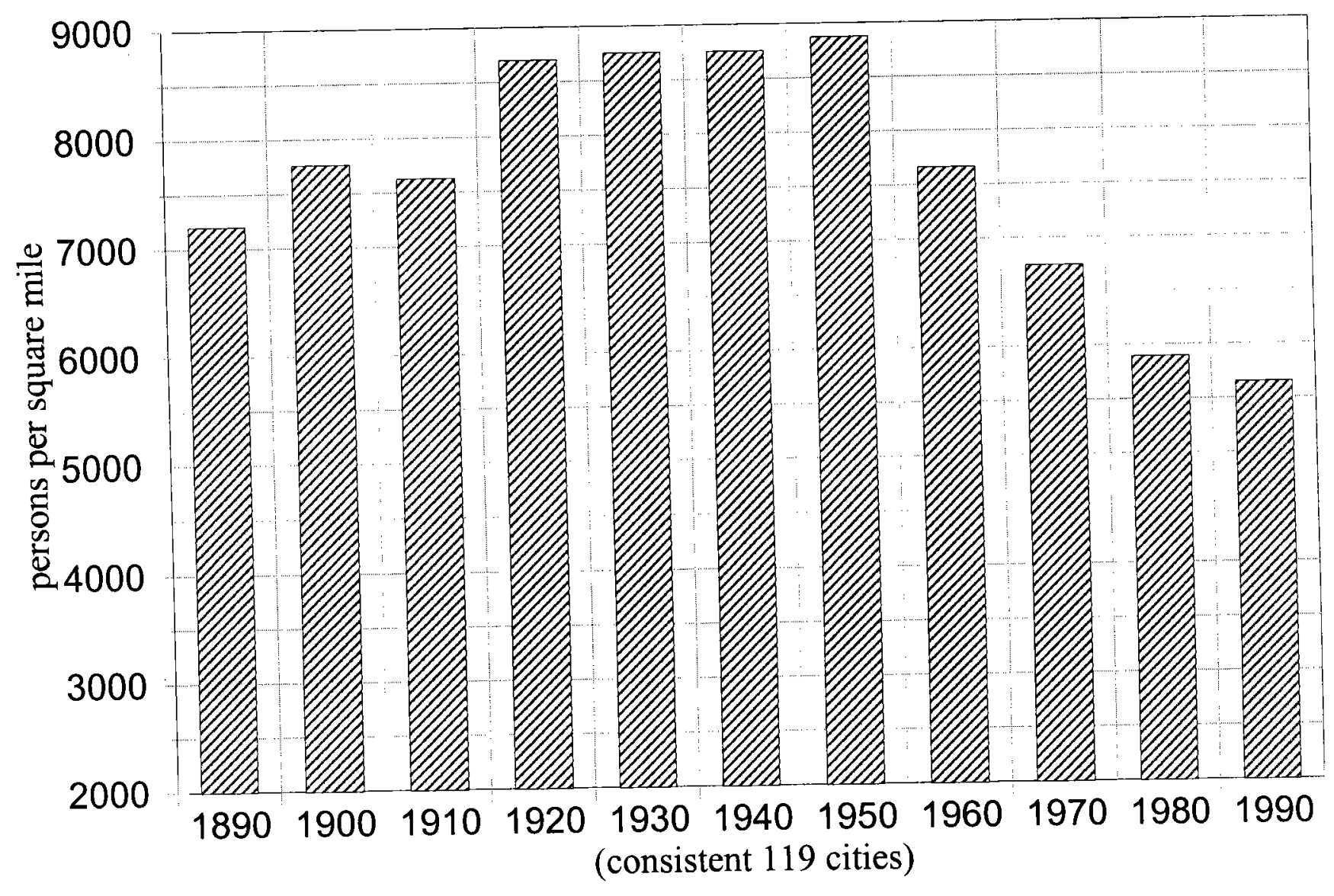


Figure 4

Density of Cities, 1890-1990

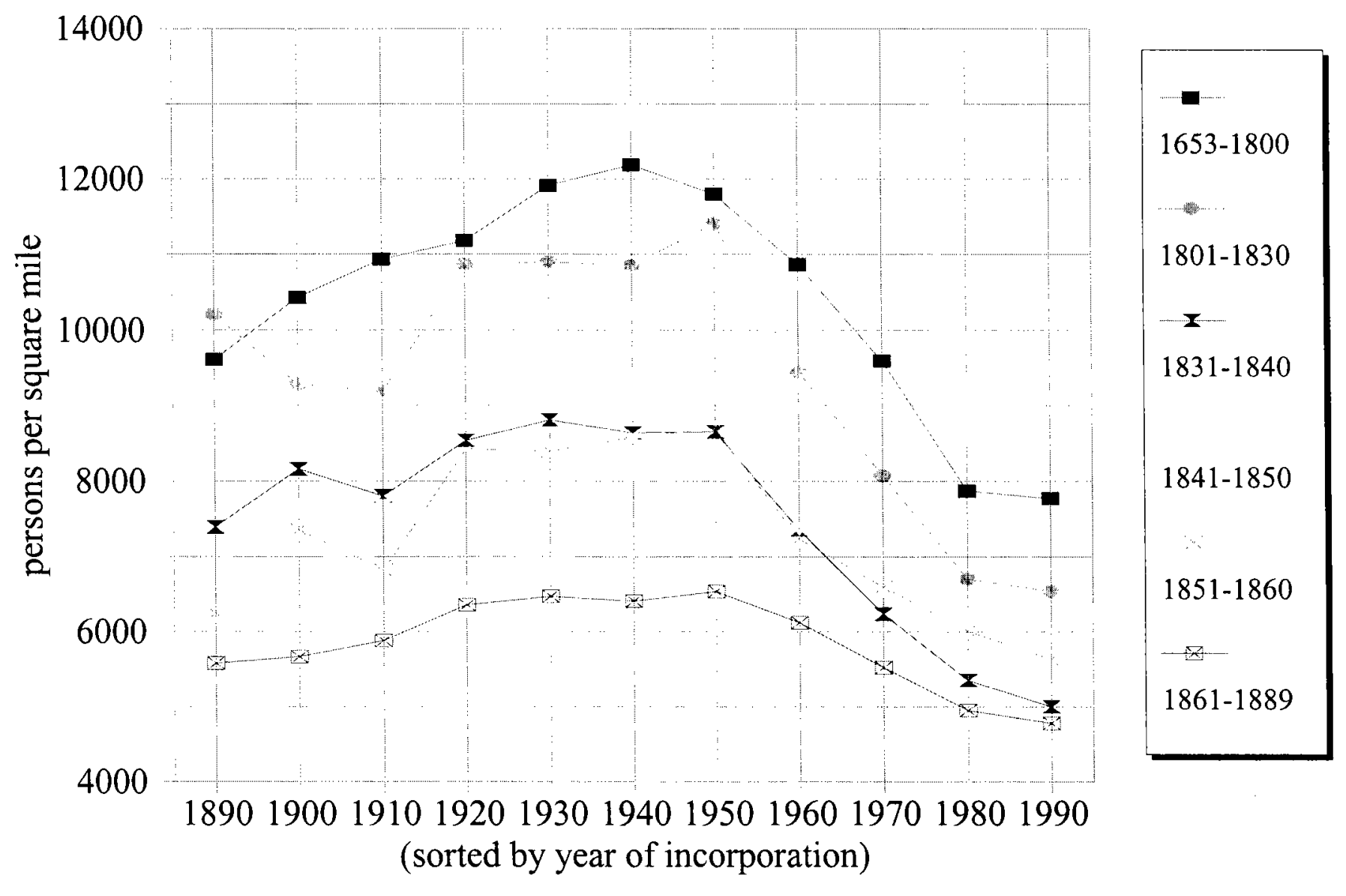


Figure 5

Density of Cities, 1890-1990

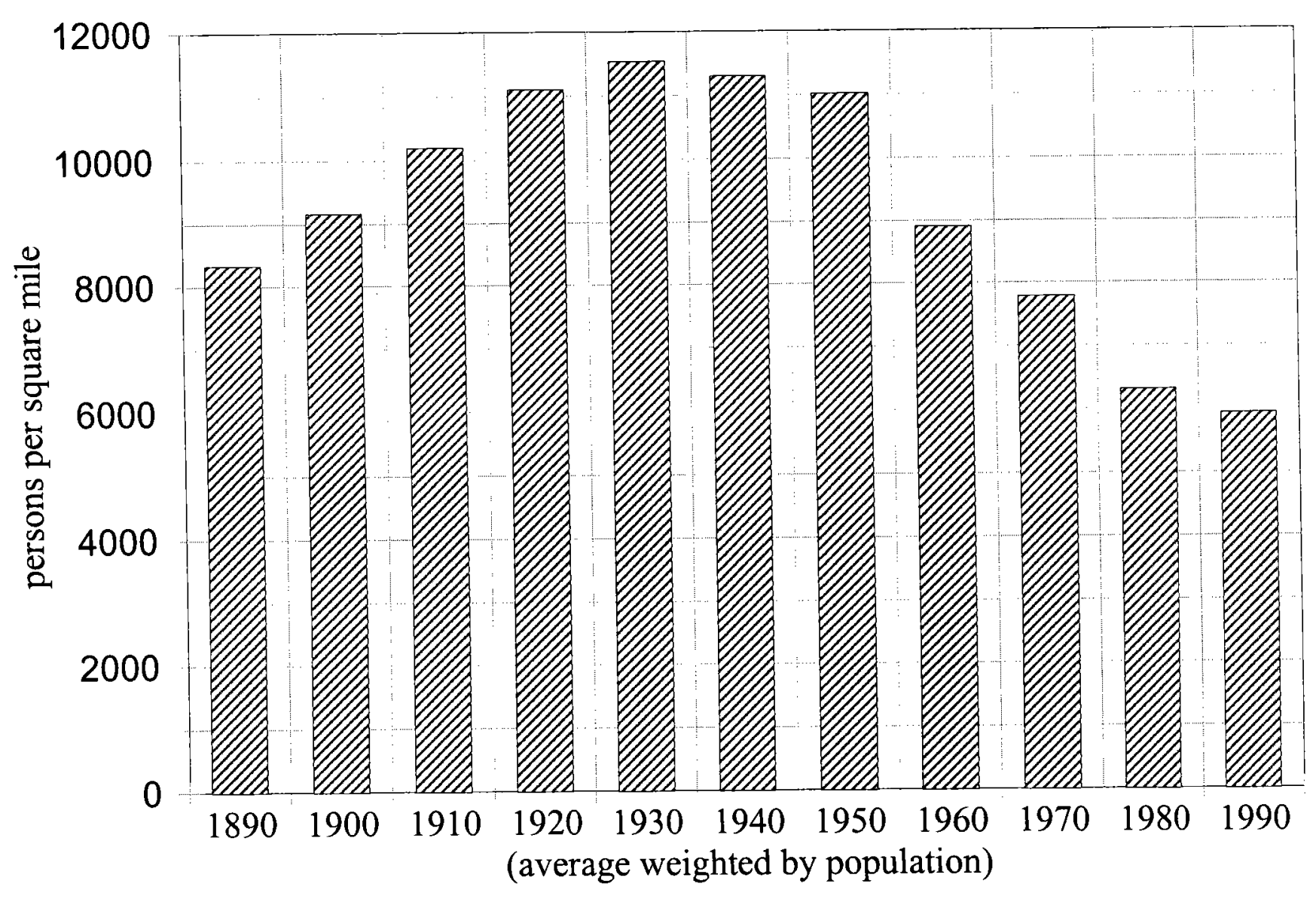


Figure 6

Density of Cities, 1890-1990

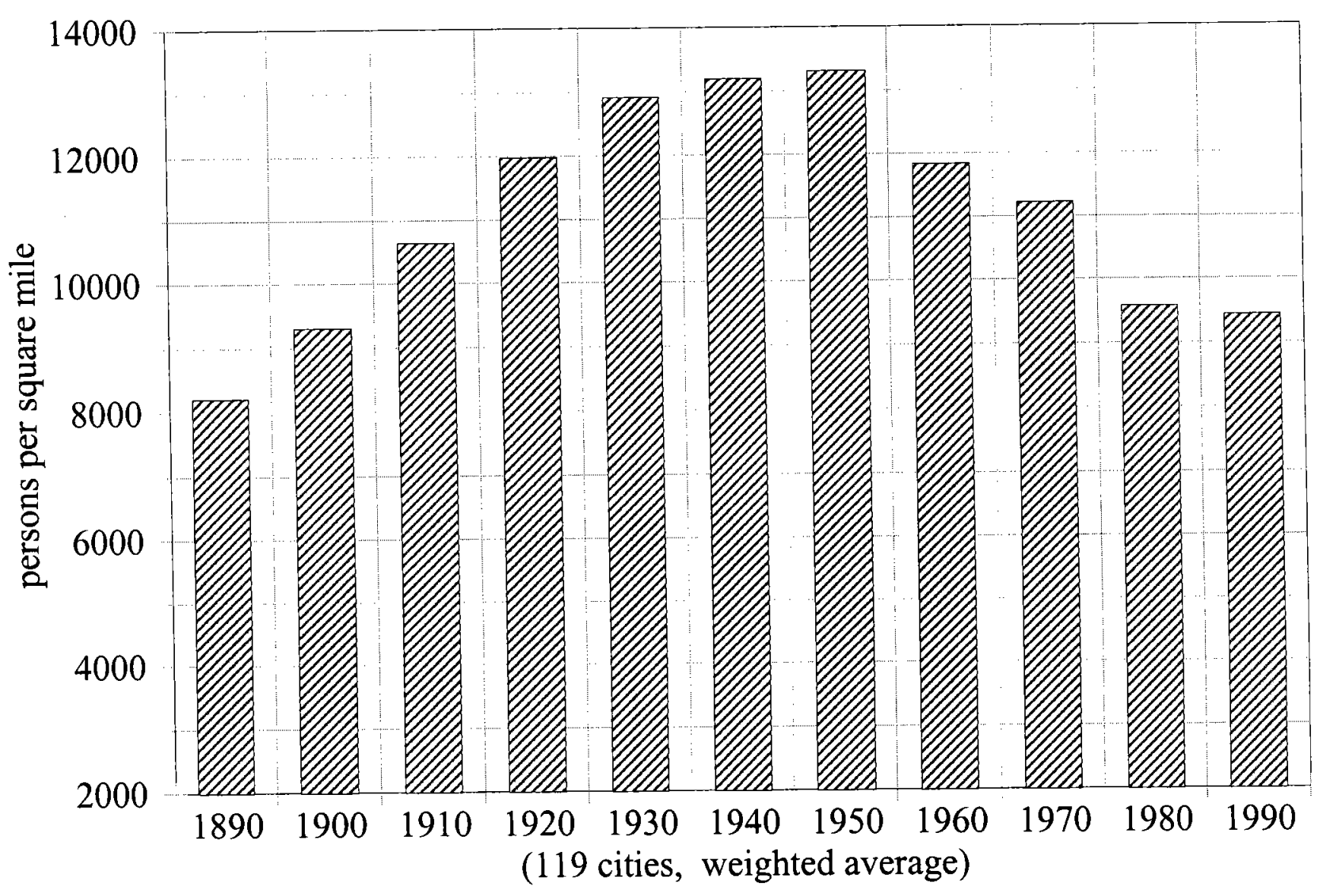


Figure 7

Density of Metro Areas, 1940-1990

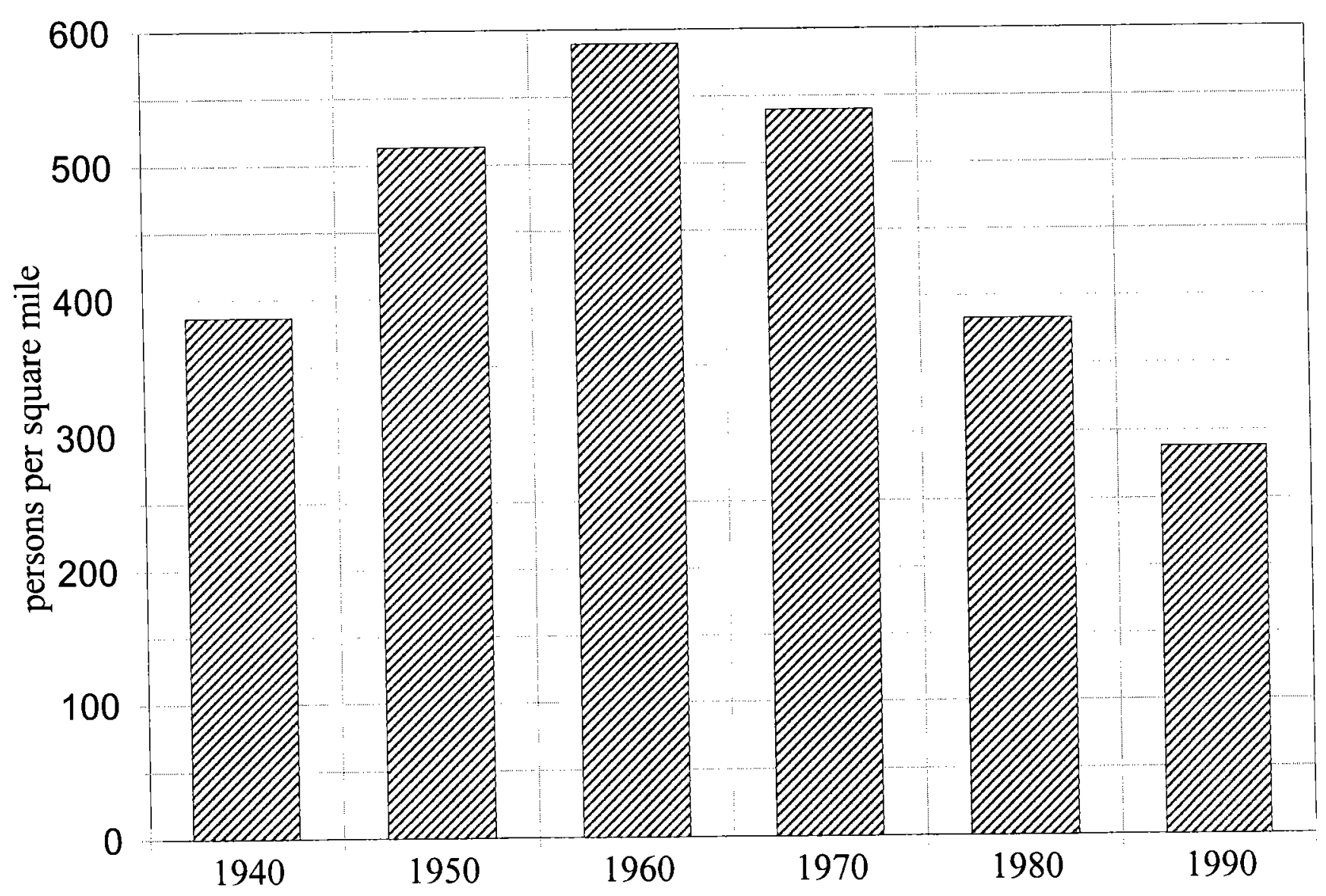


Figure 8

Density of Metro Areas, 1940-1980

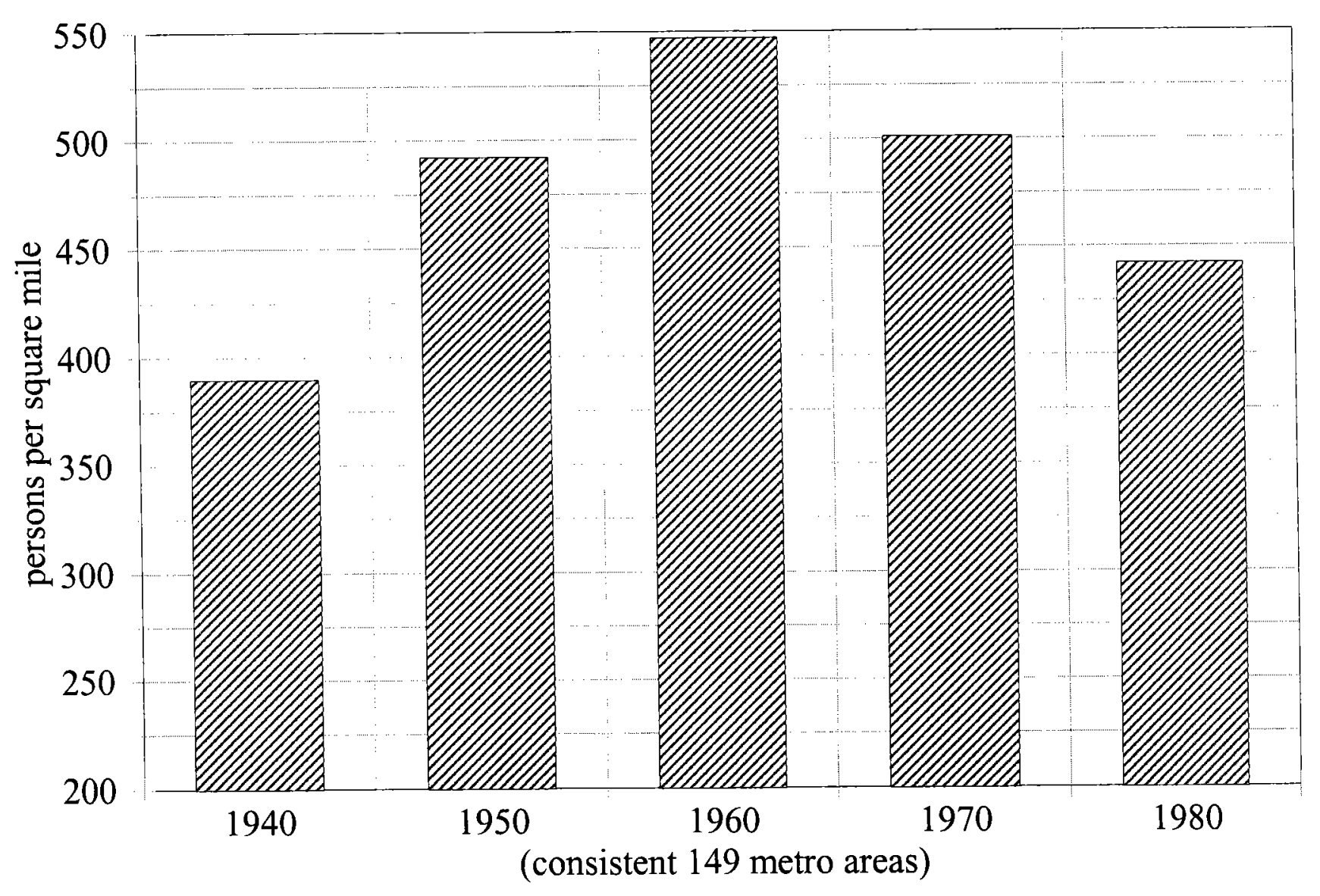




\section{References}

Alonso, William. Location and Land Use. Harvard University Press, Cambridge: MA, 1964.

Anas, Alex, Richard Arnott, and Kenneth Small. "Urban Spatial Structure," Journal of Economic Literature 36, no. 3 (1998): 1426-1464.

Bartholomew, Harland. Land Uses in American Cities. Harvard University Press, Cambridge: MA, 1955.

Berliant, Marcus and Ping Wang. "Endogenous Formation of a City With Agglomeration Externalities or Market Imperfections: Market Places in a Regional Economy," Regional Science and Urban Economics 23 (1993): 121-144.

Berliant, Marcus and Hideo Konishi. "Endogenous Formation of a City: Population Agglomeration and Marketplaces in a Location Specific Production Economy," Regional Science and Urban Economics (2000).

Black, Ducan and Vernon Henderson. "Urban Evolution in the U.S." mimeo, 1998.

Bogue, Donald J. Population Growth in Standard Metropolitan Areas 1900-1950. Housing and Home Finance Agency, Washington DC: GPO, 1953.

Brueckner, Jan K. "The Structure of Urban Equilibria: A Unified Treatment of the Muth-Mills Model," in Handbook of Regional and Urban Economics, Vol. 2 (1987): 821-845.

Carlino, Gerald A. and Edwin S. Mills. "Determinants of County Growth," Journal of Regional Science 27, no. 1 (1987): 39-54.

Carlino, Gerald A. and Satyajit Chatterjee. "Postwar Trends in Metropolitan Employment Growth: Decentralization and Deconcentration," Working Paper 99-10, Federal Reserve Bank of Philadelphia (1999).

Chatterjee, Satyajit and Gerald A. Carlino. "Aggregate Employment Growth and the Deconcentration of Metropolitan Employment," Working Paper 98-6R, Federal Reserve Bank of Philadelphia (1998).

Ciconne, Antonio and Robert E. Hall. "Productivity and the Density of Economic Activity," American Economic Review 86, no. 1 (1996): 54-70.

Clark, Colin. "Urban Population Densities," Journal of Royal Statistical Society: Series A, 114 (1951): 490-496.

Condit, Carl W. The Chicago School of Architecture. University of Chicago Press, Chicago: IL, 1964.

Deitz, Richard. "A Joint Model of Residential and Employment Location in Urban Areas," Journal of Urban Economics 44 (1998): 197-215.

Dobkins, Linda and Yannis Ioannides. "Spatial Interaction Among U.S. Cities: 1900-1990," Regional Science and Urban Economics 31, 6 (2001):801-731.

Duany, Andres, Elizabeth Plater-Zyberk, and Jeff Speck. Suburban Nation: The Rise of Sprawl and the Decline of the American Dream. North Point Press, New York: NY, 2000.

Duranton, Gilles and Diego Puga. "Diversity and Specialization in Cities: Why, Where and When Does it Matter?" Urban Studies 37, 3 (2000):533-555.

Edmonston, Barry. Population Distribution in American Cities. D.D. Heath and Company: Lexington: Massachusetts, 1975.

Fujita, Masahisa. Urban Economic Theory. Cambridge University Press, Cambridge: UK, 1989. Fujita, Masahisa, Paul Krugman, and Anthony J. Venables. The Spatial Economy: Cities, Regions, and International Trade. MIT Press, Cambridge, MA, 1999. 
Fujita, Masahisa and Jacque-Francois Thisse. Economics of Agglomeration. Cambridge University Press, 2001.

Glaeser, Edward L. "Are Cities Dying?" Journal of Economic Perspectives 12, no. 2 (1998): 139160.

Glaeser, Edward and Joseph Gyourko. "Urban Decline and Durable Housing," (2001) NBER Working Paper \#8598.

Glaeser, Edward and Matthew E. Kahn. "Decentralized Employment and the Transformation of the American City," (2001) NBER Working Paper \#8117.

Glaeser, Edward, Hedi D. Kallal, Jose Scheinkman, and Andrei Shleifer. "Growth in Cities," Journal of Political Economy 100 (1992): 1126-1152.

Glaeser, Edward, Jed Kolko, Albert Saiz. "Consumer City," Journal of Economic Geography 1 (2001): 27-50.

Greenwood, Michael and Richard Stock. "Patterns of Change in the Intrametropolitan Location, Population, Jobs and Housing," Journal of Urban Economics, 28 (1990): 243-276.

Grubb, W. N. "The Flight to the Suburbs of Population and Employment, 1960-1970," Journal of Urban Economics 11 (1982): 348-367.

Hanson, Gordon. "Scale Economies and the Geographic Concentration of Industry," Journal of Economic Geography 1 (2001): 255-276.

Hawley, Amos H. The Changing Shape of Metropolitan America: Deconcentration Since 1920. The Free Press, Glencoe, IL, 1956.

Helsley, Robert W. and William C. Strange. "Matching and Agglomeration Economies in a System of Cities," Regional Science and Urban Economics 20 (1990): 189-212.

Henderson, Vernon J. Urban Development. Oxford University Press, New York: NY, 1988.

Henderson, Vernon J., Ari Kuncoro, and Matt Turner. "Industrial Development of Cities," Journal of Political Economy 103 (1998): 1067-1090.

Kim, Sukkoo. "Expansion of Markets and the Geographic Distribution of Economic Activities: Trends in U.S. Regional Manufacturing Structure, 1860-1987," Quarterly Journal of Economics 110, no. 4 (1995): 881-908.

Kim, Sukkoo. "Economic Integration and Convergence: U.S. Regions, 1840-1990," Journal of Economic History 58, no. 3 (1998): 659-683.

Kim, Sukkoo. "Regions, Resources, and Economic Geography: The Sources of U.S. Regional Comparative Advantage, 1880-1987," Regional Science and Urban Economics, 29 no. 1 (1999): 1-32.

Kim, Sukkoo. "Urban Development in the United States, 1690-1990," Southern Economic Journal 66, no. 4 (2000): 855-880.

Konishi, Hideo. "Formation of Hub Cities: Transportation Cost Advantage and Population Agglomeration," Journal of Urban Economics 48 (2000): 1-28.

Krugman, Paul. Geography and Trade. MIT Press, Cambridge: MA, 1991.

Landau, Sarah B. and Carl W. Condit. Rise of the New York Skyscraper 1865-1913. Yale University Press, New Haven: CT, 1996.

LeRoy, Stephen F. and Jon Sonstelie. "Paradise Lost and Regained: Transportation Innovation, Income and Residential Location," Journal of Urban Economics 13 (1983): 67-89.

Macauley, Molly. "Estimating Recent Behavior of Urban Population and Employment Density Gradients," Journal of Urban Economics 18 (1985): 301-310.

Margo, Robert A. "Explaining the Postwar Suburbanization of Population in the Unites States: 
The Role of Income," Journal of Urban Economics 31 (1992): 301-310.

McDonald, John F. "Econometric Studies of Urban Population Density: A Survey," Journal of Urban Economics 26 (1989): 361-385.

McMillen, Daniel P. and John F. McDonald. "Suburban Subcenters and Employment Density in Metropolitan Chicago," Journal of Urban Economics 43 (1998): 157-180.

Mieszkowski, Peter and Edwin S. Mills. "The Causes of Metropolitan Suburbanization," Journal of Economic Perspectives 7, no. 3 (1993): 135-147.

Mieszkowski, Peter and Barton Smith. "Analyzing Urban Decentralization: The Case of Houston," Regional Science and Urban Economics 21 (1991): 183-199.

Mills, Edwin S. Studies in the Urban Structure of the Urban Economy. Johns Hopkins Press, Baltimore: Maryland, 1972.

Mills, Edwin S and Bruce W. Hamilton. Urban Economics. $4^{\text {nd }}$ Edition. Scott, Foresman and Co.: Glenview, IL, 1989.

Mills, Edwin S. and Richard Price. "Metropolitan Suburbanization and Central City Problems," Journal of Urban Economics 15 (1984): 1-17.

Muth, Richard F. Cities and Housing. University of Chicago Press, Chicago: Illinois, 1969.

Rosenthal, Stuart and William Strange. "The Determinants of Agglomeration" Journal of Urban Economics 50, 2(2001):191-229.

Small, Kenneth A. and Suenfeng Song. "Population and Employment Densities: Structure and Change," Journal of Urban Economics 36 (1994): 292-313.

Steinnes, Donald N. and Walter D. Fisher. "An Econometric Model of Intraurban Location," Journal of Regional Science 14, no. 1 (1974): 65-80.

Stern, Robert A.M., Thomas Mellins, and David Fishman. New York 1880. Monocelli Press: New York, 1999.

Thompson, Warren S. The Growth of Metropolitan Districts in the United States: 1900-1940. U.S. Department of Commerce. Washington DC: GPO, 1948.

Thurston, Lawrence and Anthony M.J. Yezer. "Causality in the Suburbanization of Population and Employment," Journal of Urban Economics 35 (1994): 105-118.

U.S. Bureau of the Census. Census of Manufactures, Washington DC: GPO, various years. , Census of Population, Washington DC: GPO, various years. , Census of Population and Housing, Washington DC: GPO, various years. , County and City Data Book, Washington DC: GPO, various years. , Financial Statistics of Cities, Washington DC: GPO, various years. , Social Statistics of Cities, Washington DC: GPO, various years. , State and Metropolitan Area Data Book, Washington DC: GPO, various years.

Warner, Sam Bass. Streetcar Suburbs: The Process of Growth in Boston, 1870-1900. Harvard University Press: Cambridge, 1962.

Weber, Adna F. The Growth of Cities in the Nineteenth Century. Cornell University Press, Ithaca: NY, 1899.

Wheaton, William. "Income and Urban Residence: An Analysis of Consumer Demand for Location," American Economic Review 674 (1977): 620-634.

White, Michelle. "Firm Suburbanization and Urban Subcenters," Journal of Urban Economics 3 (1976):323-343.

White, Michelle. "Location Choice and Commuting Behavior in Cities with Decentralized Employment," Journal of Urban Economics 24 (1988): 129-152. 